\title{
FOSSIL DECAPOD CRUSTACEANS FROM THE LOWER TERTIARY OF THE PRINCE WILLIAM SOUND REGION, GULF OF ALASKA
}

\author{
ANNETTE B. TUCKER AND RODNEY M. FELDMANN \\ Department of Geology, Kent State University, \\ Kent, Ohio 44242
}

\begin{abstract}
Sixty-five fossil brachyuran crabs, collected from rocks of the Orca Group, Tokun Formation, and Poul Creek Formation, have been assigned to six species, five of which were described previously. One of these, Pilumnoplax hannibalanus, is reassigned to Neopilumnoplax. Morphologic descriptions of Raninoides vaderensis, Eumorphocorystes naselensis, Portunites alaskensis, and Branchioplax washingtoniana are emended. Orbitoplax plafkeri $\mathrm{n}$. gen. and $\mathrm{sp}$. is described from the Poul Creek Formation on Wingham Island. The diagnosis of age for the Orca Group has been problematic. However, the well-preserved brachyurans, Branchioplax washingtoniana, Neopilumnoplax hannibalanus, and Raninoides vaderensis, provide corroborative evidence for an Eocene or older age for the rocks. Alaskan decapods include species common to the entire Pacific coast north of California, as well as species endemic to Alaska.
\end{abstract}

\section{INTRODUCTION}

B RACHYURAN DECAPOD crustacean fossils have been collected from a number of localities in the Prince William Sound region, Gulf of Alaska, within the Orca Group, the Tokun Formation, and the Poul Creek Formation. The brachyuran fauna is composed primarily of goneplacids, with relatively fewer portunids and raninids.

The Orca Group embraces the oldest sedimentary sequence in the Gulf of Alaska that is known to contain crabs. Brachyurans, though not abundant, are some of the best preserved of the Orca fossils. Generally, the microfauna within the Orca Group is poorly preserved, and age-diagnostic molluscs are found in only one locality, making the age of the Orca Group problematic. Therefore, it is the purpose of this study to use the decapods to refine the interpretation of the age of the Orca Group.

The well-preserved decapod fossils from the younger Tokun and Poul Creek Formations are compared with those from Washington and Oregon, as well as with those from the Orca Group. Some Pacific West Coast decapod assemblages have been used as diagnostic of the Oligocene Lincoln molluscan stage (Jeletzky, 1973). However, recent work by Snavely et al. (1980) indicated that decapods described by Rathbun (1916) from Koitlah Point, Olympic Peninsula, Washington, were from what is presently known as the Hoko River Formation, and are late Eocene in age, rather than Oligocene. These recent re-evaluations of the stratigraphy of the Pacific West Coast place some doubt on other decapod ranges as established by Rathbun (1926).

The principal purposes of this paper are to: 1) examine and describe the fossil decapod crustaceans from the Alaska localities, 2) emend original descriptions based upon more complete specimens than were originally available, 3 ) compare the decapod taxa to those from better known assemblages in Washington and Oregon, and 4) assess the biochronological usefulness of these taxa. Additionally, where possible, an attempt is made to suggest synecological relationships based on associated fauna.

Specimens in this study were collected over field seasons from 1953 to 1983. Most of the collections were made by George Plafker as part of continuing exploration of the Gulf of Alaska coastal regions by the United States Geological Survey.

LOCATION AND STRATIGRAPHY

General. - The study area is located along the coast of the central part of the Gulf of Alaska (Figure 1). Specimens were collected from two localities near the mouth of Galena Bay in northeastern Prince William Sound. Other localities are on the west side of Bering Lake, the southeastern tip of Wingham Island, and Kayak Island. Localities near Galena Bay are referred to the Orca Group. One locality near Bering Lake is referred to the Tokun Formation. All of the remaining localities are within the Poul Creek Formation.

To assign an age to each formation, invertebrate faunas from the study localities were compared with faunas from formations on the Pacific Coast from British Columbia south to California. Primarily, molluscan faunas were compared with similar faunas representative of the Pacific Coast Paleogene stages as established by Weaver (1944).

Orca Group. - The Orca Group probably underlies most of Prince William Sound and is exposed over an area of about $21,000 \mathrm{~km}^{2}$ in Prince William Sound and in the Chugach Mountains (Winkler, 1976). Orca exposures are known on most of the islands in Prince William Sound. The unit is thought to range in age from late Paleocene to middle Eocene (Figure 2). Correlative rocks also occur on all but the southeastern tip of Wingham Island and possibly form the core of the Ragged Mountains (Plafker and MacNeil, 1966).

Accurate estimates of the thickness of the Orca Group are currently not possible, owing to the repetitious tight folding and faulting of the rocks and the lack of adequate biostratigraphic control. The contact with the underlying Valdez Group has not been established with any certainty (Plafker and MacNeil, 1966). In addition, the top of the Orca Group also has not been recognized (Plafker and MacNeil, 1966). However, if considered a distinct unit, the Orca Group is estimated to be as much as 6,000 to $10,000 \mathrm{~m}$ thick (Plafker et al., 1985).

The Orca Group originally was described by Schrader in 1900 and most recently was studied by Plafker and MacNeil (1966), Addicott and Plafker (1971), Tysdal et al. (1976), Winkler (1976), Marincovich and McCoy (1984), Plafker et al. (1985), and Plafker, 1987. Tysdal et al. (1976) subdivided the Orca Group into three conformable units. In ascending order, these units are the volcanic unit, the volcanic and sedimentary unit, and the sedimentary unit. The volcanic unit consists of altered tholeiitic basalt. pillow flows, pillow breccia, and massive columnar flows (Tysdal et al., 1976; Winkler, 1976; Plafker et al., 1985). The volcanic and sedimentary unit of the Orca Group consists of "interbedded light- to dark-gray, thin- to thick-bedded, fine- to medium-grained sandstone and interbedded siltstone" (Tysdal 


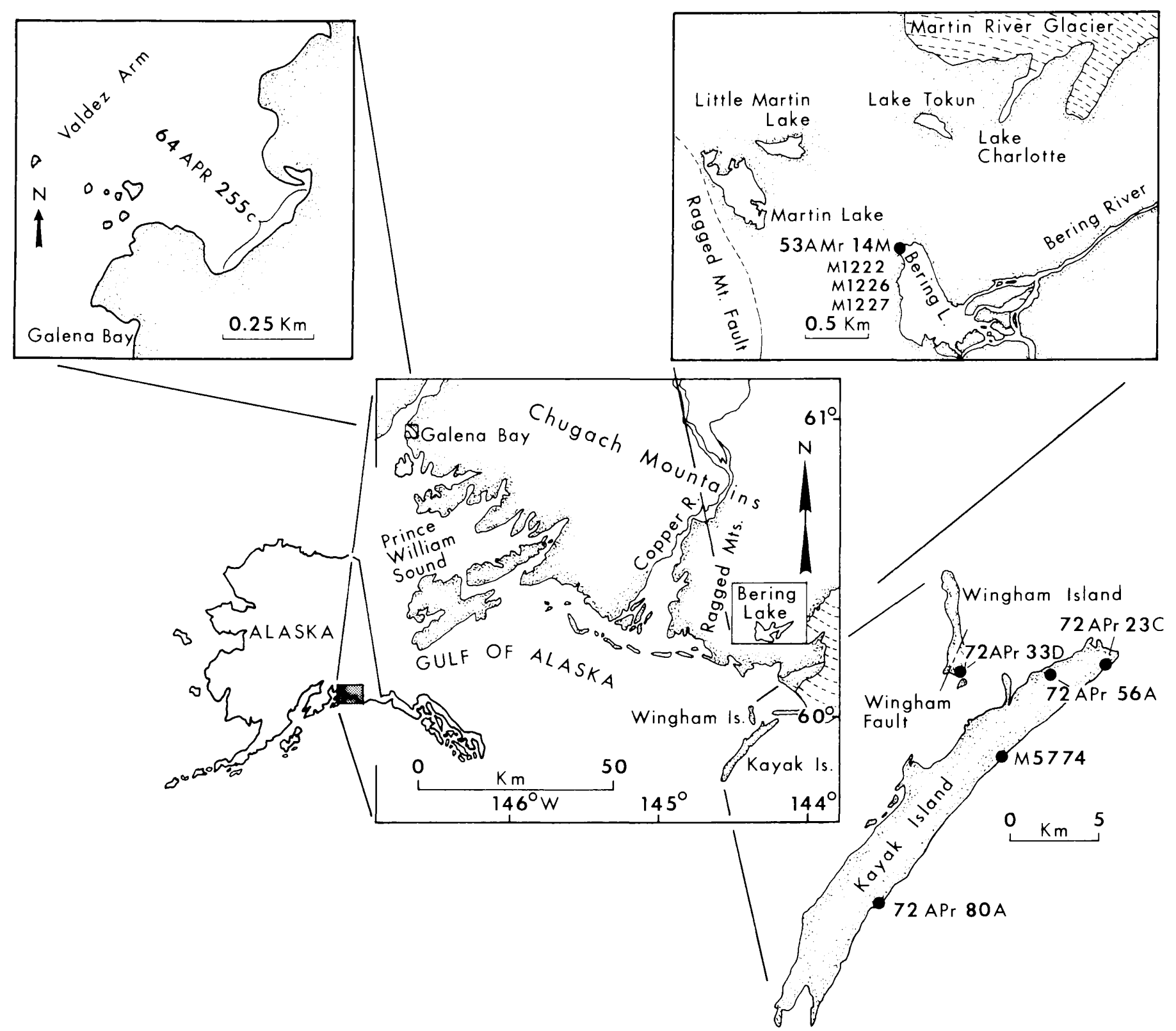

FIGURE 1 -Location map showing geography of collection area, central Gulf of Alaska, and sites from which decapod fossils have been collected. Locality numbers are referred to in descriptions of individual taxa.

et al., 1976, extended map caption). The sedimentary unit consists of dark-gray, thin- to thick-bedded, fine-grained, tightly cemented sandstones which grade upward into siltstones and are considered to be a flysch-like sequence deposited at bathyal depths (Tysdal et al., 1976; Winkler, 1976; Marincovich and McCoy, 1984; Plafker et al., 1985).

Concretions of dense calcareous argillite occur as spheres or oblate spheroids within the mudstone matrix of a diamictite occurring within the Orca Group on both sides of Galena Bay (Plafker and MacNeil, 1966). These concretions attain a maximum diameter of $12 \mathrm{~cm}$ and an estimated 10 percent contain pieces of, or entire, fossil crabs and a few mollusks (Plafker and MacNeil, 1966). Crabs occurring within the Orca Group include Branchioplax washingtoniana Rathbun, Neopilumnoplax han- nibalanus (Rathbun), and Raninoides vaderensis Rathbun. Mollusks identified from the Orca Group include Acila decisa (Conrad), Periploma cf. P. eodiscus Vokes, and Musashia (Nipponomelon) sp. cf. M. (N.) shikamai Moore. This megafauna was collected primarily from a locality near the mouth of Galena Bay, and based on it Plafker et al. (1985) suggested an Eocene age for the Orca Group, possibly middle Eocene.

Although the Orca Group contains a microfauna, it is sparse and poorly preserved and indicates a Paleogene age for these rocks. Some of the foraminiferans and radiolarians found within the Orca Group suggest that it may have been deposited as early as late Paleocene (Addicott and Plafker, 1971; Blome, written communication to Plafker, 1985). The minimum age of the Orca Group is indicated by discordant plutons that intruded the Orca 
at 50.5-53.5 $\pm 1.6 \mathrm{Ma}$ (Plafker et al., 1985). This places the upper age limit within the early to middle Eocene (Berggren et al., 1985).

Tokun Formation. - The Tokun Formation was first described by Martin (1908) and more recently was studied by Tysdal et al. (1976), Wolfe (1977), Marincovich and McCoy (1984), and Plafker (1987). The formation is exposed on both shores of Lake Tokun and extends to the north and northeast toward the Martin River Glacier and toward the western shore of Lake Charlotte (Martin, 1908). The Tokun also occurs on the west shore of Bering Lake and is conformable with the superjacent Poul Creek Formation (Tysdal et al., 1976) (Figure 2).

The Tokun Formation attains a maximum thickness of 1,067 $\mathrm{m}$ and consists of sandy shales overlain by sandstones. In the upper part, sandstones are interbedded with massive siltstones, calcareous siltstones, and silty limestones (Martin, 1908; Tysdal et al., 1976). Calcareous concretions occur in the upper part of the Tokun Formation. Throughout the Katalla District, the Tokun Formation has produced a meager megafauna; however, fossil crabs and mollusks are common at some localities (Tysdal et al., 1976).

The Tokun Formation was interpreted to have been deposited in a deltaic environment (Plafker, 1987). It has been described as intertonguing with a continental coal-bearing facies, the Kulthieth Formation, on Kayak and Wingham Islands (Plafker, 1987). The total age range for the Tokun Formation has been determined to be late Eocene through earliest Oligocene (MacNeil et al., 1961). The basal Tokun Formation yields a fauna that suggests Tejon Stage or late Eocene. Included within this fauna are Acila cf. A. decisa (Conrad), Gari cf. G. columbiana (Weaver and Palmer), Pitar cf. P. californianus Conrad, Ficopsis cf. F. cowlitzensis Weaver, Molopophorus cf. M. tejonensis Dickerson, Turritella uvasana Conrad, Whitneyella $\mathrm{cf}$. $W$. coosensis Turner, and Whitneyella cf. W. sinuata Gabb var. (Wolfe, 1977). In addition, toward the east Perse washingtonensis (Weaver) was collected from the basal Tokun Formation; this species also suggests a late Eocene age (Wolfe, 1977). A specimen tentatively identified as Turcicula columbiana Dall, when compared with the fauna from Washington and Oregon, suggests that part of the Tokun Formation could be as young as Keasey age (Wolfe, 1977).

Poul Creek Formation. - Taliaferro (1932) originally proposed the Poul Creek Formation for rocks exposed along Poul Creck and elsewhere. Some of the exposures within the study area, which have been correlated with, and referred to, the Poul Creek Formation, were originally described by Martin (1908) as the Katalla Formation. The Katalla Formation was correlated with the Poul Creek Formation, based on similarities in lithology and age (Plafker, 1987) (Figure 2).

The Poul Creek within the study area is exposed in the hilly area south of Bering Lake between the lake and the Katalla River, and along the base of the eastern slope of the Ragged Mountains (Martin, 1921). The formation also is exposed on Kayak Island, on the southeast part of Wingham Island (Martin, 1908; Plafker, 1974), and in the region north and northeast of Bering Lake (Martin, 1908; Tysdal et al., 1976).

In the Katalla region, the Poul Creek Formation is approximately 1,311-1,708 $\mathrm{m}$ thick. In ascending order, the formation was divided into the Split Creek Sandstone Member, the Basin Creek Member, and the Burls Creek Member. The basal contact with the Tokun Formation is sharp and conformable (Tysdal et al., 1976).

The Basin Creek Member is a resistant unit consisting of very fine grained quartzofeldspathic sandstone interbedded with silt-

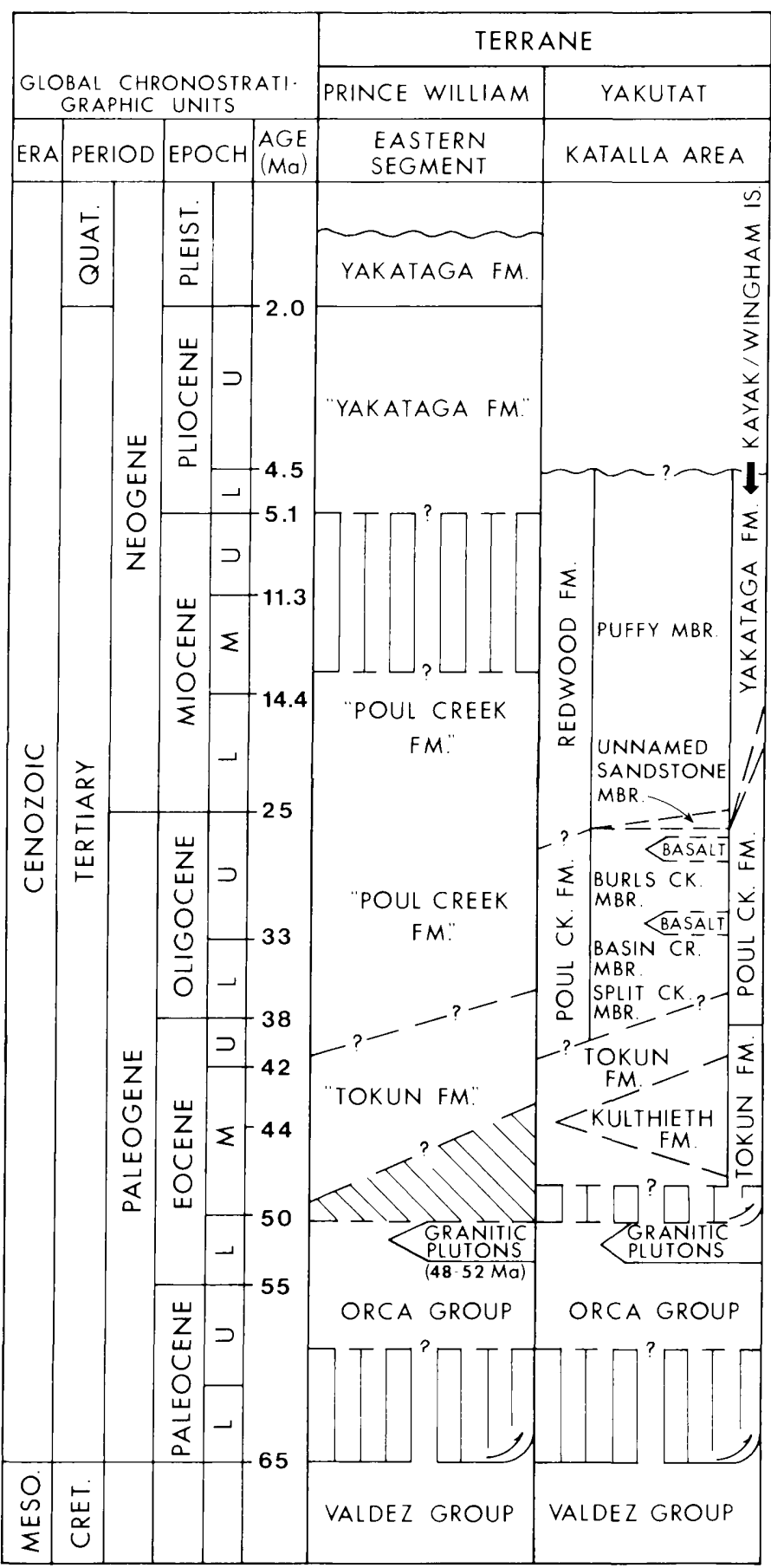

FIGURE 2-Correlation chart for Cenozoic rocks in the Prince William Sound region, showing relationship of rock units referred to in the text. (Modified from Plafker, 1987.)

stone and sandy siltstone which is locally glauconitic (Tysdal et al., 1976). Hard, round calcareous concretions containing fossil crabs are found within the siltstone beds. This member merges conformably and gradationally with the underlying Split Creek Member (Tysdal et al., 1976). The Poul Creek Formation is in conformable contact with the strata above (Tysdal et al., 1976).

The Poul Creek Formation has been interpreted to have been deposited in a marine environment at sublittoral to bathyal 
depths in a basin which was variously free circulating or restricted (Tysdal et al., 1976). Pacific coast, age-diagnostic mollusks, such as Acila, Bathybembix, Liracassis, and Turritella, occur throughout the Poul Creek and suggest an Eocene to late Oligocene age for this unit (Marincovich and McCoy, 1984). In addition, the Split Creek Sandstone Member has yielded a fauna that is considered by Vokes (in Wolfe, 1977) to be similar in age to the Molopophorus stephensoni zone, or earliest middle Oligocene, as represented by the Lincoln molluscan stage.

\section{SYSTEMATIC PALEONTOLOGY}

Order DECAPODA Latreille, 1803

Suborder Pleocyemata Burkenroad, 1963

Infraorder BRACHYURA Latreille, 1803

Section Podotremata Guinot, 1977

Subsection ARCHEOBRACHYURA Guinot, 1977

Superfamily RANINOIDEA de Haan, 1841

Family RANINIDAE de Haan, 1841

Genus RaninOIDES H. Milne Edwards, 1837

Type species. - Ranina laevis Latreille, 1825.

\section{RANINOIDES VADERENSIS Rathbun, 1926 Figure 3.1, 3.2}

Diagnosis.-Carapace obovate, greatest width posterior to front half; transversely convex, surface smooth; fronto-orbital region less than extreme width of carapace.

Emendation to description. - Carapace obovate in outline, anterior one-half widest, greatest width 55-60 percent total length; entire surface finely and unevenly granulate, granules more coarse anteriorly and laterally; carapace only slightly convex longitudinally, much more so transversely; lateral margins turned under.

Width of fronto-orbital region about 75 percent extreme width; fronto-orbital region widest posteriorly, tapering anteriorly; orbits directed somewhat toward long axis. Dorsal margin of each orbit marked by two deeply grooved, open fissures, lateralmost fissure about twice as deep as wide, approximately parallel to lateral margin of orbit; interior fissure wider, approximately parallel midline of carapace. Outer orbital tooth bifid, inner branch short, outer branch extending farther forward than interior teeth; frontal margin of carapace forms rostrum that extends well beyond orbits, slightly downturned. Rostrum long, triangular, with slightly convex granulate margins, keeled medially; keel subtle, not extending beyond posterior frontal region, bounded laterally by shallow sulci.

Anterolateral margin of carapace convex in outline, bearing one pair of short hepatic spines directed more forward than outward; posterolateral margin weakly sigmoid, carapace tapering to narrow, convex posterior margin; posterolateral margin with narrow beaded marginal rim; margin turned under carapace; posterior margin convex with narrow marginal rim.

Midline of carapace smooth; cardiac region very poorly defined, slightly elevated, marked by two subtle arcuate grooves; other regions undefined.

Shallow furrow along sinuous transverse line posteriad frontoorbital region marks anterior of subtle transverse ridge; lateral part of furrow pustulose; hepatic regions with pustulose prosopon.

Locality, type specimens, and occurrence. - Specimens referable to this taxon were collected from the Galena Bay localities within the Orca Group. Specimens USNM 431251, USNM 431253, and USNM 6649414 are from locality 64 APr 255C (Figure 1). Locality 83APr 114 yielded only one specimen possibly referable to Raninoide's vaderensis (USNM 431250). This locality is described as occurring near Johnson Cove, about one mile north of the entrance to Galena Bay, and is not located on Figure 1. These four specimens are deposited in the United States National Museum of Natural History.

The holotype, deposited in the Burke Memorial Washington State Museum, University of Washington, Seattle, is from " 1 mile west of junction of Olequa and Stillwater Creeks on the latter near Vader, Lewis County, in section 30, township 11 north, range 2 west; upper Eocene series, Tejon Formation" (Rathbun, 1926, p. 93).

The four specimens in this study are preserved as molds of the interior (Figure 3 ). One is broken across the carapace (USNM 649414), another (USNM 43125) is partially exfoliated with part of replaced integument preserved. Two of the specimens (USNM 431250 and USNM 431251) are very poorly preserved and only tentatively referred to this taxon.

Remarks. - The four specimens referred to Raninoides vaderensis represent one of two decapod species within the Orca Group. Two specimens well enough preserved to measure range in size from 33.5 to $40 \mathrm{~mm}$ long. Representatives of Raninoides vaderensis are characterized by having an ovate carapace that is very convex transversely. The differences between $R$. vaderensis and $R$. lewisanus Rathbun, 1926, are subtle. The frontoorbital width of $R$. lewisanus is greater, the anterolateral spine is more forward, the posterolateral margin is not sigmoidal, and the transverse convexity is much greater (Rathbun, 1926). $R a$ ninoides eugenensis Rathbun, 1926, differs from $R$. vaderensis by being less convex transversely. The rostrum of the former extends forward less than the orbital spines. The rostrum of $R$. eugenesis is bounded on either side by spines, which do not occur on $R$. vaderensis. The extreme width of $R$. eugenensis is just posterior to the lateral spines. The transverse sinuous ridge on the anterior dorsal carapace of $R$. vaderensis is a distinguishing feature not observed on other species.

In addition to the holotype, Rathbun (1926) described $R$. vaderensis from specimens occurring within a middle Eocene series along the Umpqua River at "Basket Point" in Douglas County, Oregon. Extant species of this genus can be found in water from 20 to $240 \mathrm{~m}$, and on sandy, shelly, or muddy bottoms (Rathbun, 1937). Other species are known from coastal waters off North Carolina, and as far south as Brazil in the Atlantic and from the Gulf of California south to Ecuador in the Pacific (Rathbun, 1937).

The raninids have a unique shape and organization which make their exact systematic position difficult to interpret (Williams, 1984). It is often difficult to determine which characteristics are derived and which are primitive because of specializations related to burrowing. Stevčič (1971) suggested that the elongated body, lengthened mouth parts, and incompletely flexed abdomen were related to the burrowing habit.

Genus EumorPhOCORYSTES Binkhorst, 1857

Type species. - Eumorphocorystes sculptus Binkhorst, 1857.

EUMORPHOCORYSTES NASELENSIS Rathbun, 1926 Figure 4.1, 4.2

Diagnosis. - Carapace broadly ovate or egg-shaped; anterolateral margins arcuate, converging sharply anteriorly; anterolateral spines about one-third distance from front; Fronto-orbital margin about one-half total width of carapace; coarsely punctate; median ridge entire length of carapace, including rostrum.

Description. - Carapace broadly ovate in outline, widest behind anterolateral teeth; greatest width about 60 percent total length; carapace convex longitudinally, very convex transversely; lateral margins turned slightly under, taper posteriorly to anterolateral teeth, becoming straight. 

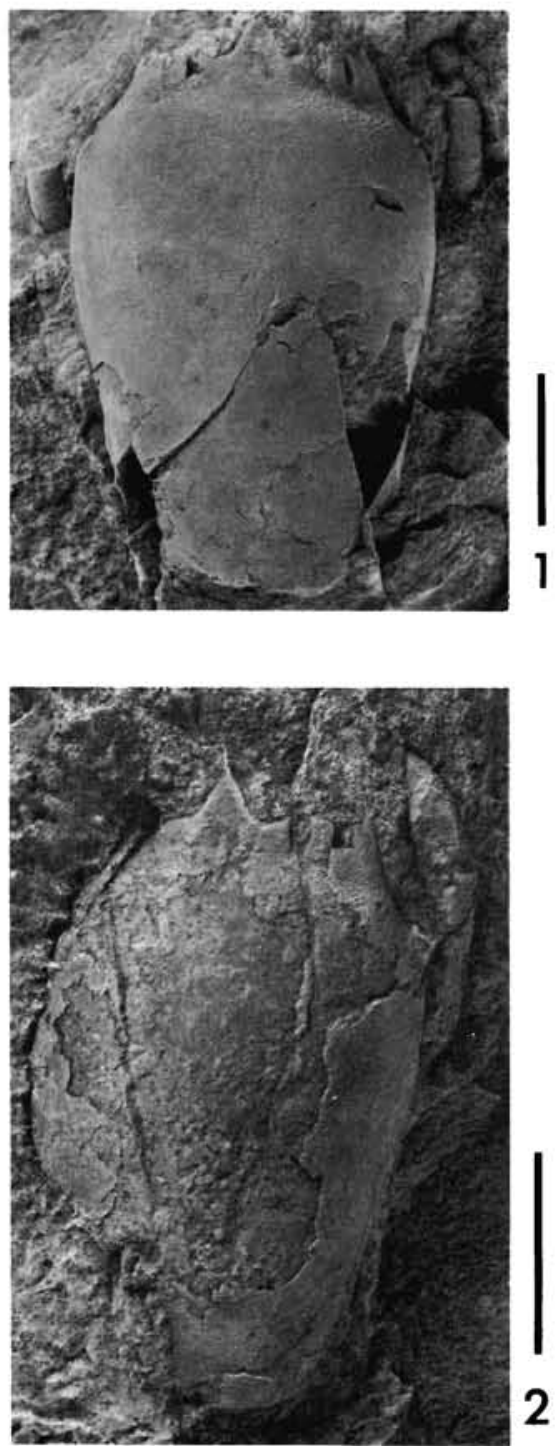

FIGURE 3-Raninoides vaderensis Rathbun, dorsal views. 1, USNM 649414; 2, USNM 431253. Scale bars equal $1 \mathrm{~cm}$.

Width of fronto-orbital region slightly less than one-half greatest width; fronto-orbital region widest posteriorly, tapering slightly anteriorly; orbits directed forward. Dorsal margin of each orbit marked by two U-shaped open fissures, wider than deep, directed posteriorly; approximately parallel to long axis of animal; outer tooth of orbit longest; two inner teeth progressively shorter, second tooth bifid. Frontal margin of carapace produced to form rostrum, not extending beyond orbits; not downturned. Rostrum long, triangular, margins slightly convex, inflated; rostrum keeled medially; keel subtle, extending posteriorly into well-defined medial ridge that extends entire length of carapace; keel bounded laterally by shallow sulci.

Anterolateral margins of carapace convex in outline, turned under at lateral angle, becoming straight and tapering posteriad lateral angle; one pair long, stout lateral spines; spines directed outward and very slightly forward; posterolateral margin convex, converging posteriorly to blunt posterolateral corner; posterior margin slightly concave.

Midline of carapace strongly keeled for entire axial region; urn-shaped cardiac region gently and broadly swollen, tapering,

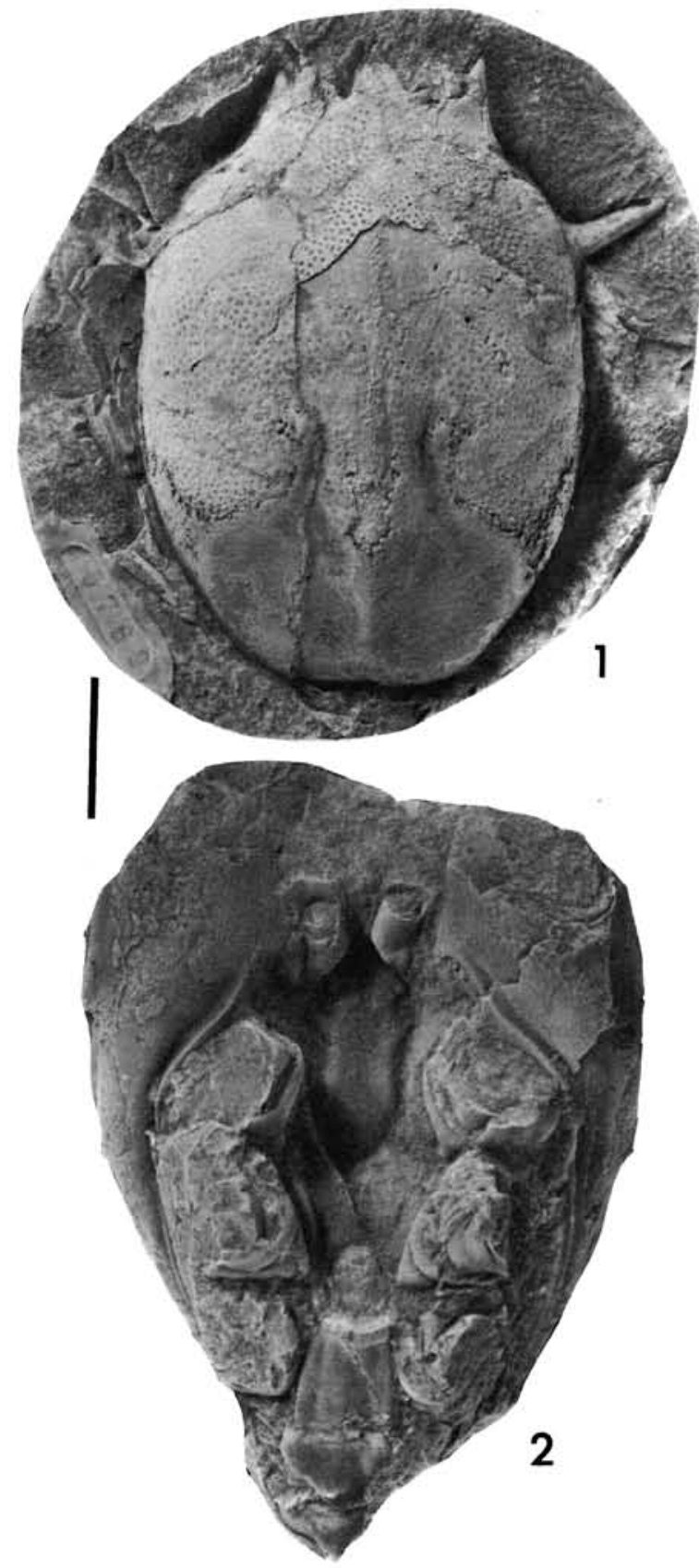

FIGURE 4-Eumorphocorystes naselensis Rathbun. 1, dorsal view of USNM 431255; 2, ventral view of CAS 29180. Scale bar equals 1 $\mathrm{cm}$.

merging into keeled axial region posteriorly; two deeply etched branchiocardiac grooves as arcuate impressions; remainder of cardiac groove subtle; two arcuate muscle scars, directed toward axis of carapace, lying just anteriad cardiac grooves; pair of gastric pits either side of midline at anterior termini of muscle scars; metabranchial region slightly less inflated than remaining branchial region; dorsal carapace covered by large punctae or pits.

Sternum narrow, elongate; elements 1-3 narrow anteriorly, broadening at midlength to form rounded, triangular termination separated from element 4 by narrower, parallel-sided part; 
element 4 with narrow anterior processes directed anterolaterally, forming widest part of sternum, narrowing at midpoint, wider posteriorly; axis of sternum slightly concave anteriorly, becoming deeply depressed posterior to element 4 .

Abdominal somites uniformly narrow, somites 3-5 bear median, anteriorly directed spines; telson longer than wide, tapering posteriorly, axial region raised.

Appendages unknown.

Locality, type specimen, and occurrence. - The type specimen, CAS 61807.01, is deposited in the California Academy of Sciences, San Francisco. Collections from this study are deposited there and in the United States National Museum of Natural History in Washington, D.C.

Rathbun (1926) described Eumorphocorystes naselensis from one specimen collected near the Nasel River in Washington. Subsequently, Jeletzky (1973) identified $E$. naselensis from Nootka Island, British Columbia. In each case, E. naselensis was identified from rocks considered to be Oligocene in age.

Five specimens in this study, referable to $E$. naselensis, were collected from the Poul Creek Formation on Kayak Island at localities 72APr 23C (USNM 431256 and USNM 431257), 72APr 80A (USNM 431255), and M5774 (USNM 431254), and from an unknown locality near Redwood Creek, Alaska (CAS 29180).

Remarks. - The five specimens referable to this taxon are preserved as partially exfoliated molds of the interior with some part of replaced integument remaining on the dorsal surface of the carapaces. The lateral spines are not preserved in their entirety. The ventral surface has been exposed on one specimen (CAS 29180). Ambulatory limbs are not preserved.

Representatives of Eumorphocorystes naselensis exhibit several characters justifying placement in the Raninidae. Essential characters include an elongate carapace that does not cover the proximal abdominal terga, and flat chelae with a slightly deflected fixed finger. Eumorphocorystes sculptus Binkhorst, 1857, type species of the genus, embodied specimens with strong, anteriorly directed anterolateral spines, a strong axial ridge, and oblique granulated ridges (Glaessner, 1969).

Rathbun (1926) assigned E. naselensis to Eumorphocorystes based on the egg-shaped body, the median ridge, and the narrow fissures of the front region. Rathbun suggested that $E$. naselensis strongly resembled Ranidina willapensis Rathbun, 1926. Ranidina willapensis has a carapace that is similar in outline and is similarly ornamented. It also bears one pair of stout, lateral spines, anarrow anterior and posterior, and a thickened midsection (Rathbun, 1926). Eumorphocorystes naselensis differs in having a median ridge, a more convex carapace, and more anteriorly placed lateral spines (Rathbun, 1926). The sternum of $E$. naselensis does not resemble any of the Ranidina, confirming Rathbun's judgement that the species does not belong with that genus.

Some characteristics of E. naselensis differ from E. sculptus. Eumorphocorystes naselensis does not show the oblique granulated ridges considered characteristic of the genus. Spines of $E$. naselensis are located more posteriorly than in E. sculptus and are much more robust. The anterolateral margin of $E$. naselensis is considerably longer, more convex, and much more anteriorly convergent than in E. sculptus.

Eumorphocorystes naselensis does demonstrate characteristics similar to $E$. schencki Rathbun (1932) and E. leucosiae Rathbun (1932). Each species bears large punctae on the dorsal surface of the carapace which give the appearance of pits and each has a characteristic egg-shaped carapace.

In terms of outward appearance, this species bears a marked resemblance to Llreidus alseamus Rathbun, 1932; however, the latter tends to be more gracile, to have more delicate lateral spines, to be smaller, and to have a very subtle median ridge. Confirmation of the distinctiveness of the two species lies in comparison of the sternal elements. The sternum of $L$. alseanus (Feldmann, 1989, p. 65) is typical of Lyreidus in that element four is slightly flared into two lobes anteriorly, whereas that region is narrow and elongate, flaring into narrow projections in $E$. naselensis. To our knowledge, the sternum has not been previously described in a species of Eumorphocorystes, so that the description constitutes the first record of that structure.

Section Heterotremata Guinot, 1977

Superfamily PORTUNOIDEA Rafinesque, 1815

Family PORTUNIDAE Rafinesque, 1815

Subfamily CARCININAE Macleay, 1838

Genus PORTUNites Bell, 1858

Type species. - Portunites incerta, Bell, 1858.

PORTUNites ALASKensis Rathbun, 1926

Figure 5.1, 5.2

Diagnosis. - Carapace not much broader than long; front dentate, orbits large; anterolateral margin with three or four teeth posterior to orbital tooth, last tooth longest; longitudinal ridge on branchial region extending obliquely from posterolateral corner to axial corner of branchial region; moderate length chelipeds.

Emendation to description. - Medium size carapace, outline hexagonal, widest between lateral teeth; slightly convex transversely, more so longitudinally; sides vertical to slightly underturned.

Orbits large with concave upper margins, extending from front slightly obliquely toward posterior; upper margins granulate along rims; eyestalk slender, relative to size of orbit. Anterolateral margin, measured from extraorbital tooth to lateral tooth, less than 33 percent total length; arcuate and converging anteriorly; posterolateral margin about 60 percent total length, converging posteriorly, bearing slight depression at posterior corner; posterior margin nearly straight with slight ridge.

Regions well defined by broad, shallow grooves; swollen; epigastric regions small, gently swollen areas on either side of midline posteriad frontal region; protogastric regions broadly swollen, on either side of mesogastric region; transverse ridge connecting midpoints of protogastric regions; mesogastric region narrow, elongate, extending along midline of carapace from just posterior to epigastric, merging into metagastric region; metagastric region broadly inflated, triangular, with concave sides, convex base; urogastric region swollen, just posterior to metagastric; poorly defined by grooves; broad, shallow, sinuous cervical groove, interrupted medially by metagastric region; cardiac region triangular, apex directed posteriorly; anterior corners with inflated bosses, each with centrally located pustule; posterior apex less swollen, no pustule. Ventral aspect of carapace not preserved.

Fixed finger of major cheliped bearing tooth at innermost angle of occlusal surface, directed toward palm; movable finger carinate along superior surface; carpus slightly longer than broad, bearing strong triangular inner spine; merus with two outer spines, one near articulation with carpus, one more proximal.

Meri of ambulatory legs flattened, ovate in cross section, about five times longer than broad; transversely ridged dorsally and on posterior edge; carpus about four times longer than broad; dactylus of fifth pereiopod ovate, paddle-like.

Locality, type specimens, and occurrence. - Holotype and several paratypes are deposited in the Natural History Museum of Los Angeles County, but were not studied. One paratype, USNM 354169 , is deposited in the United States National Museum of Natural History, Washington, D.C. Collections from this study 
are deposited in the United States National Museum of Natural History.

Rathbun (1926) describe Portunites alaskensis from Oligocene age rocks along the east branch of Redwood Creek in Alaska. Two specimens from Oligocene age rocks along Pearl Creek in Alaska were also referred to this taxon. Additionally, Portunites alaskensis was identified by Rathbun (1926) from five Oligocene localities in Washington and one upper Oligocene locality near Eugene, Oregon. Jeletzky (1973) reported the occurrence of Portunites alaskensis from rocks of Oligocene age in British Columbia.

Specimens referable to this taxon were collected from localities M1222 (USNM 431261), M1226 (USNM 431258, USNM 431259 , and USNM 431262), and M1227 (USNM 431262) near Bering Lake, and on Kayak Island at locality 72APr 56A (USNM 431260), from the lower part of the Poul Creek Formation (Figure 1).

Of the five specimens referable to this taxon, one (USNM 431260 ) is preserved as a partially exfoliated mold of the interior which has some replaced integument remaining on the dorsal surface of the carapace. Much of the left chela is preserved. The right chela is preserved as a mold of the exterior; it also bears the mold of a tooth at the inner occlusal surface. The remaining specimens also are preserved as molds of the interior. The paddle-like dactylus of the last walking appendage is preserved on only one of the specimens (USNM 431258). The specimens range in length from $15.8 \mathrm{~mm}$ to $26.5 \mathrm{~mm}$.

Remarks. - Rathbun (1926) placed Portunites alaskensis with the Portunidae, based upon possession of a broad, flat carapace with the greatest width between the lateral spines, large or elongate orbits, a dentate anterolateral margin, a dentate front margin, and flattened fifth pereiopods, usually with oval dactyli (Glaessner, 1969).

Rathbun (1926) suggested that the width of $P$. alaskensis should be 1.5 times the length when measured in front of the spine at the lateral angle. However, the width was found to be less than 1.5 times the length based on specimens measured in this study. This suggests that there is individual variation in length-width ratios within this species and that this character should not be used in keying this genus. Indeed, Warner (1977) observed that some crabs exhibit a change in length-width ratios with growth of the carapace.

This species is easily distinguished from its congeners by its shape. The carapace of $P$. alaskensis is more square, the anterolateral margin is shorter, and the orbits are larger than other species within the genus (Rathbun, 1926). Portunites triangulum Rathbun bears a triangle of three teeth near the inner angle formed by the branchial region, and a broader mesogastric region (Rathbun, 1926). The epigastric and protogastric lobes of $P$. triangulum each bear a medial tubercle not found on either Portunites insculpta Rathbun or P. alaskensis. Portunites alaskensis has a slight depression at the posterolateral corner which is not obvious on either $P$. triangulum or $P$. insculpta. This depression may have been used as a resting place for the fifth pereiopod.

There are no known extant species of Portunites. It can be inferred from its paddle-like fifth pereiopods that Portunites alaskensis was not limited to living on the substrate but was a swimmer. In addition, the poor preservation of the lateral spines suggests that the carapace was light enough to enhance the ability to swim. It is probable that this ability to swim adapted $P$. alaskensis to many water depths, from neritic to bathyal, as long as there was an available food supply (Jeletzky, 1973).

Extant Atlantic species of portunid crabs with paddle-like fifth pereiopods tolerate marine, brackish, and even fresh water (Williams, 1984). They often can be found inhabiting estuaries. In
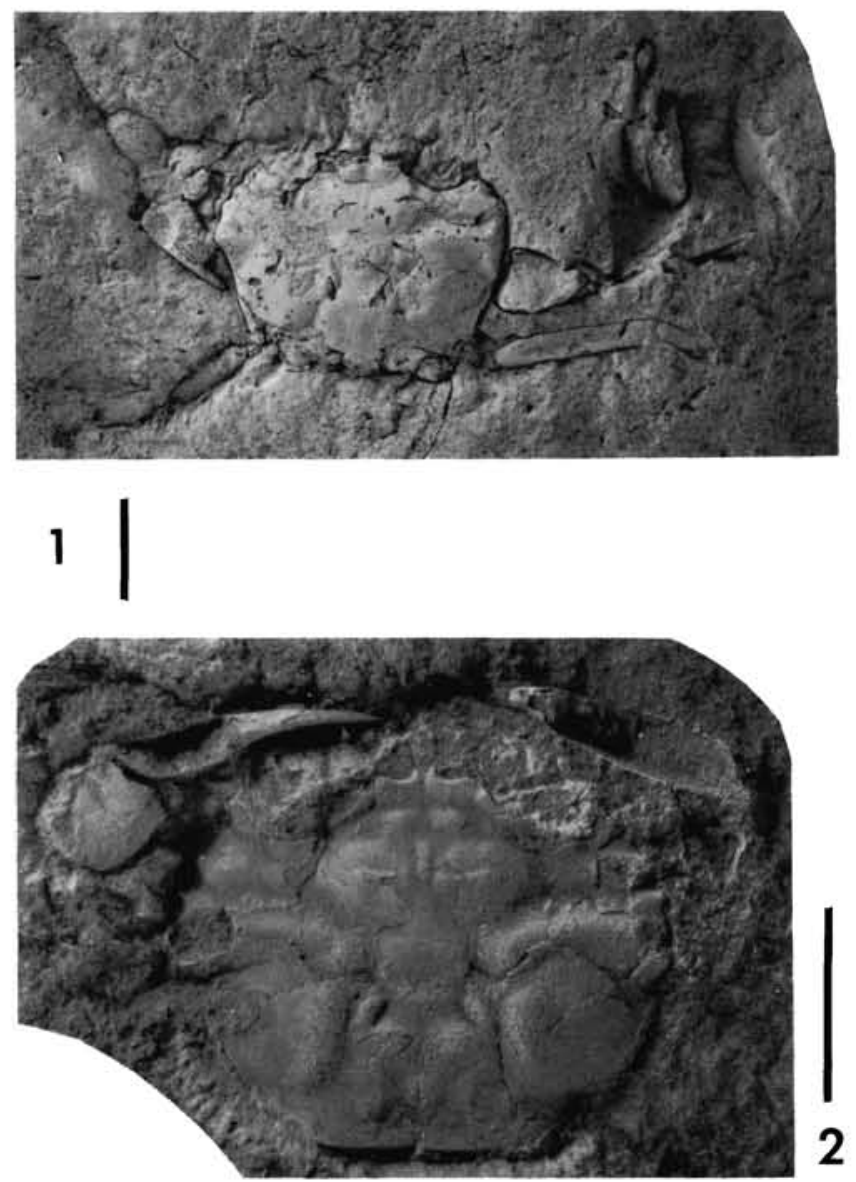

FIGURE 5-Portunites alaskensis Rathbun, dorsal views. 1, USNM $431258 ; 2$, USNM 431260. Scale bars equal $1 \mathrm{~cm}$.

addition, swimming portunids also seem to be quite tolerant of a broad range of temperatures. Though well adapted to neritic environments, these crabs occur at greater depths on a variety of substrates.

Superfamily XANTHOIDEA Dana, 1851

Family GONEPLACIDAE Macleay, 1838

Subfamily CARCINOPLACINAE H. Milne Edwards, 1852

Genus BranChIOPLAX Rathbun, 1916

Figures 6.1-6.4, 7.1, 7.3

Type species. - Branchioplax washingtoniana Rathbun, 1916.

BRANCHIOPLAX WASHINGTONIANA Rathbun, 1916

Diagnosis. -Subquadrate carapace, slightly broader than long; front straight, orbits shallow, directed forward; anterolateral margins convex, converging anteriorly, dentate, bearing five teeth; posterolateral margin weakly convex, converging somewhat posteriorly; posterior margin straight, strongly heterochelate.

Emendation to description.-Subquadrate carapace, slightly broader than long, length about $85 \%$ width; widest at anterolateral angles, slightly convex longitudinally, less so transversely; front about 33 percent total width, medially sulcate; margin weakly convex, bearing shallow medial notch.

Orbits shallow, directed more forward than out; extraorbital tooth as rectangular corner; dorsal margin of orbit bearing one deeply grooved, slightly open fissure about two-thirds back from fronto-orbital angle, parallel to axis of carapace; shallower fissure anterior to orbital tooth, directed toward axis of carapace; 

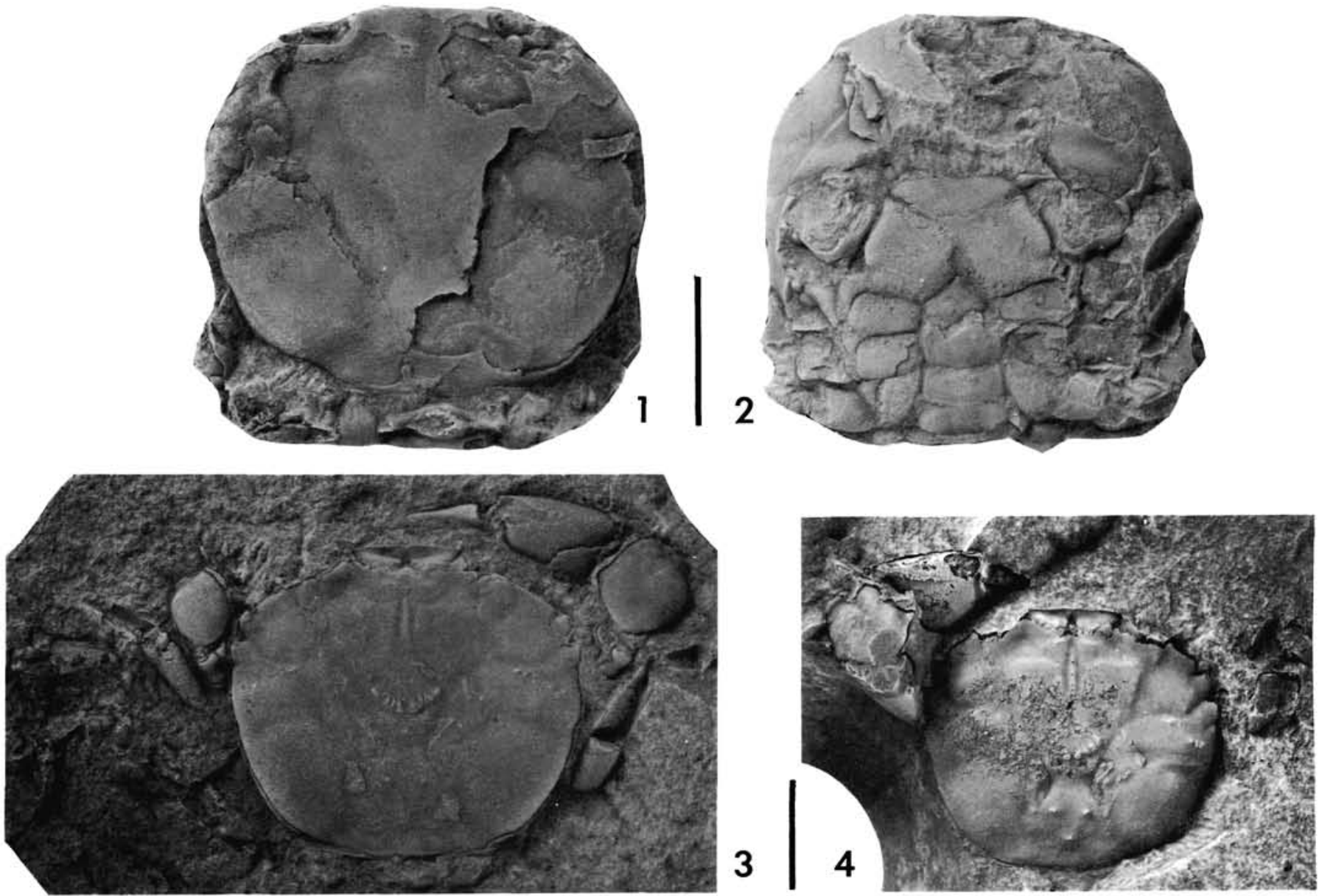

FIGURE 6-Branchioplax washingtoniana Rathbun. 1, dorsal view of USNM 431263; 2, ventral view of USNM 431263; 3, 4, dorsal views of USNM 431265 and USNM 431270. Scale bars equal $1 \mathrm{~cm}$.

dorsal margin of orbit flares upward forming groove posteriad orbital ridge.

Anterolateral margin about 33 percent total length of carapace, convex in outline, converging anteriorly from anterolateral angle; with five teeth including extraorbital tooth; first two teeth coalesced to form straight edge about same length as orbit; third tooth largest, extending slightly beyond second; fourth less robust; fifth reduced or absent.

Posterolateral margin more weakly convex, about 60 percent total length; gently converging posteriorly; posterolateral angle as rounded corner; posterior margin straight to slightly convex, about 1.2 times front margin, ridged, with narrow beaded rim.

Regions well defined by shallow grooves; epigastric region gently swollen, merging with front; protogastric region broad, ovate swelling on either side of mesogastric region; basal margin straight, diverging posteriorly from midline; mesogastric region narrow sulcate extension of anterior metagastric, sides only slightly flared; medially keeled; metagastric region triangular; sides straight, base arcuate; anterior extends gradually into mesogastric; medially swollen, bearing two pairs of nodes on either side of midline of carapace; urogastric region crescentshaped, just posterior to base of mesogastric; not medially divided; bearing single median node; hepatic regions gently swollen, outer margins bearing first two anterolateral teeth.

Cervical groove a sinuous U-shaped curve originating just posteriad hepatic region and extending along posterolateral mar- gin of protogastric lobes to base of metagastric region; interrupted medially by urogastric region.

Cardiac region urn-shaped, defined by shallow narrow groove; with three nodes as apices of triangle, directed posteriorly; branchiocardiac grooves deeply etched arcs directed toward axis of carapace; distance between most interior part of grooves about one-eighth extreme width of animal. Intestinal region a flat area posterior to cardiac region.

Epibranchial regions small, just posteriad hepatic, outer margins bear fourth and possibly fifth anterolateral teeth; mesobranchial regions with arcuate raised ridges directed anteriorly, more swollen distally; metabranchial regions broadly swollen, well delimited by wide shallow grooves.

Abdomen of seven distinct somites with swollen axial regions and raised, granulate pleural regions; somites one and two of about equal length, one wider than two; swollen medially; both arcuate, with arc directed anteriorly; both very granulate across entire width of somite, more densely so on pleural margins; strongly ridged medially; somite three widest, pleural margins strongly curved posteriorly; four narrower, more gently arcuate than three, narrowing posteriorly; five and six more gently arcuate with five longer but narrower than four, six longer than five; five and six with gently convex pleural regions; seven an equilateral triangle, apex rounded.

Sternum long, narrow, punctate; margins raised, granulate; sternites one through three indistinct; four as broad as long, 


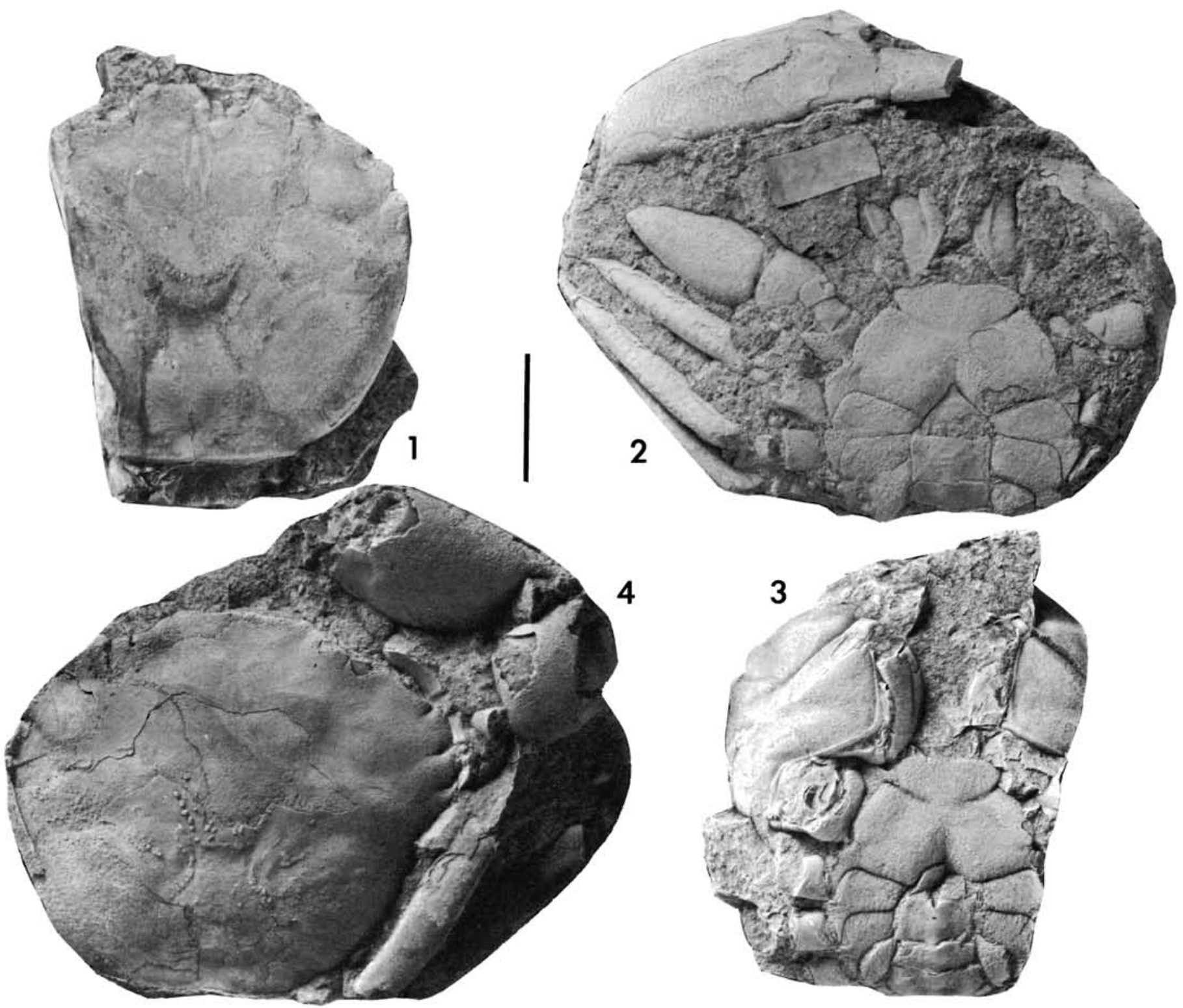

FIGURE 7-Dorsal and ventral views comparing 1 and 3, USNM 431271, Branchioplax washingtoniana and 2 and 4, USNM 431281, Neopilumnoplax hannibalanus. Scale bar equals $1 \mathrm{~cm}$.

largest of sternites; five and six wider than long; seven with convex posterior margin and sinuous anterior margin; eight reduced, not obvious.

Pterygostomian region triangular; posterior margin raised granulate ridge; central part broadly swollen; buccal frame diverges anteriorly; ischium of third maxillipeds longer than broad, slightly arched or curved toward axis of animal, diverging anteriorly.

Animal strongly heterochelate; meri of first appendage as wide as long, constricted medially; carpi as broad as long, with anterior tooth on inner surface; manus of major chela strong, stout with long, slender fixed finger flexed downward, dactylus unknown.

Walking appendages somewhat compressed; ovate in cross section; dactyli lanceolate.

Measurements. - Measurements (in mm) are listed in Table 1.
Localities, type specimens, and occurrence. - The holotype, not studied, is deposited in the Peabody Museum at Yale University. Specimens studied here include: USNM 431263 (locality unknown), USNM 431264 (64 APr 255C), USNM 431265 (M1227), USNM 431266 (64 APr 255C), USNM 431267 (64 APr 255C), USNM 431268 (64 APr 255C), USNM 431269 (53 AMr 14M), USNM 431270 (64 APr 255C), and USNM 431271 (45 AMr 149), deposited in the United States National Museum of Natural History.

Branchioplax washingtoniana was described by Rathbun (1926) from rocks, considered to be Oligocene in age, on the Olympic Peninsula in Washington. Subsequently, these rocks, known as the Hoko River Formation, near Koitlah Point, have been assigned a late Eocene age based on age-diagnostic foraminiferans and molluscs (Snavely et al., 1978). Other specimens identified by Rathbun (1926) from Washington were from the 
TABLE 1 -Representative measurements (in $\mathrm{mm}$ ) of Branchioplax washingtoniana.

\begin{tabular}{|c|c|c|c|c|c|c|c|c|c|}
\hline Specimen number & $\mathrm{L}$ & $\mathrm{W}$ & $\mathrm{F}$ & $\mathrm{O}$ & $\mathrm{F}-\mathrm{O}$ & $\mathrm{Al}$ & $\mathrm{Pl}$ & $\mathrm{P}$ & $\mathrm{B}-\mathrm{C}$ \\
\hline USNM 431263 & 27.6 & 31.0 & 11.0 & 5.9 & 22.8 & 9.0 & 18.5 & - & 5.6 \\
\hline USNM 431270 & 24.0 & 26.7 & 8.7 & 4.8 & 18.0 & 8.6 & 14.1 & - & 4.5 \\
\hline USNM 431265 & 29.6 & 34.0 & 10.6 & 5.9 & 23.4 & 9.5 & 17.9 & 16.8 & 4.0 \\
\hline USNM 431271 & 32.2 & - & 10.5 & 7.0 & 24.5 & - & - & - & 5.5 \\
\hline USNM 431267 & 20.0 & 22.2 & - & - & - & - & 10.0 & 12.0 & 3.2 \\
\hline
\end{tabular}

$\mathrm{L}=$ length, $\mathrm{W}=$ width, $\mathrm{F}=$ front margin, $\mathrm{O}=$ supraorbital margin, $\mathrm{F}-\mathrm{O}=$ fronto-orbital length, $\mathrm{Al}=$ anterolateral margin, $\mathrm{Pl}=$ posterolateral margin, $\mathrm{P}=$ posterior margin, $\mathrm{B}-\mathrm{C}=$ width between branchial-cardiac grooves, $\mathrm{C}=$ length and width of right carpus.

Clallam Formation, which is Miocene in age (Snavely et al., 1978). In addition, Rathbun (1926) identified $B$. washingtoniana from the Bering Lake area of Alaska. These were assigned an Oligocene age.

In this study, eight specimens are referable to $B$. washingtoniana. Six of these are from the Orca Group, near Galena Bay. Two were collected along the west shore of Bering Lake; one from the Tokun Formation; the stratigraphic position of the other is unknown. Two additional specimens were examined, and their characters applied to the emended description. One of these (USNM 431263) was collected by Scott McCoy during field research in Alaska, and later donated by the Amoco Company to the U.S. Geological Survey. The other specimen (USNM 43127 1) was collected from the unnamed member of the Poul Creek Formation in the vicinity of Bering Lake, Alaska, at locality $45 \mathrm{AMr} 149$. Due to a change in numbering systems, this locality could not be indicated accurately on the locality map. This specimen was from the collection at the United States National Museum of Natural History.

Specimens are preserved as molds of the interior within wellindurated concretions. Many have partially preserved, attached appendages (USNM 431265 and USNM 431270). Each of the two additional specimens is preserved as a complete cephalothorax with the ventral surface well exposed.

Remarks. - Rathbun erected the genus Branchioplax in 1916 to accommodate one species. Essential characters included an arcuate anterolateral margin that is dentate, orbits of moderate size that are directed forward, a posterolateral margin that is longer than the anterolateral margin and is moderately convergent, and a front that is not emarginate.

Characters used to place Branchioplax washingtoniana with the Goneplacidae are the hexagonal shape, the straight front margin, the dentate anterolateral margin, and the convergent posterolateral margin. Goneplacids share many characters with the Xanthidae, so much so that the two families are considered to merge (Williams, 1984). Many of the characters used to distinguish the two families include male sexual characteristics, such as the position of the male genital opening. Although the opening cannot be seen on fossils, the position of the first three abdominal segments and their relationship to the seventh and eighth sternites can be compared to those illustrated by Guinot (1969a, 1969b, 1969c) and the position of the genital opening can be inferred from these comparisons. In addition, the relative width of the fronto-orbital region can be used to distinguish the two families. The width of the fronto-orbital region never exceeds 80 percent of the extreme width within the Xanthidae; however, within the Goneplacidae the region can be as much as 90 percent of the extreme width (Williams, 1984). Because Branchioplax washingtoniana has a fronto-orbital width which ranges from 67 to 74 percent of the extreme width (Table 1). this character is not useful in this case.

Within the Goneplacidae, Branchioplax washingtoniana was placed with the Carcinoplacinae (Glaessner, 1969). Characters for this subfamily include a transversely hexagonal outline of the carapace, a fairly wide front, orbits of moderate size, a welldefined epistomal region, a square-cut buccal frame that is usually closed by the third maxillipeds, and maxillipeds with a subquadrate merus. Additionally, the base of the third segment of the abdomen of the male covers the entire space between the last pair of walking legs (Sakai, 1976). All of these characters obtain for $B$. washingtoniana.

Branchioplax washingtoniana is an extinct species; however, goneplacids, in general, are considered a deep-water group living on a variety of substrates. Members of this family are found at many different depths and are often found living at the edge of the continental shelf (Williams, 1984).

Subfamily Euryplacinae Guinot, 1969b

Genus Neopilumnoplax Serène in Guinot, 1969b

Type species. - Pilumnoplax sulcatifrons Stimpson, 1858.

NEOPILUMNOPLAX HANNIBALANUS (Rathbun, 1926) Figures 7.2, 7.4, 8.1-8.5

Diagnosis. - Carapace broader than long; front about onethird total width, margin gently convex, orbits oblique; anterolateral margin convex, with five teeth including extraorbital tooth, first two teeth coalesced; posterolateral margin converges posteriorly; posterior margin narrow, concave.

Emendation to description. - Carapace hexagonal, slightly broader than long, slightly convex longitudinally; ranges from 15.3 to $22.4 \mathrm{~mm}$ in length; widest at fourth lateral tooth; flanks turned slightly under at anterolateral angle and anterior angle, taper posteriorly.

Front gently convex, not produced; medially sulcate with no medial emargination; about one-third total width; posterior margin defined by deep groove; anterolateral margin convex, converging anteriorly, with five anterolateral teeth including extraorbital tooth, first two teeth coalesced forming edge about same length as orbit, third largest, fifth reduced; posterolateral margin convex, converging posteriorly; posterolateral corner a re-entrant; posterior margin narrow, concave; raised edge on rim, beaded.

Orbit shallow, extending obliquely, with 1 fissure about twothirds width of orbit from front, another at external orbital corner; furrow at front corner; upper margin slightly sinuous; extraorobital tooth rectangular in shape, dull.

Regions poorly defined by shallow grooves; epigastric region weakly swollen; protogastric region oblate lobes, tapering to lateral borders of metagastric region; mesogastric region medially ridged, sulcate region on midline of carapace, margins of region slightly flared; sides of medial ridge straight, region terminates anteriorly in dull point just posteriad front where frontal sulcus arises; metagastric region triangular, lateral margins slightly concave, posterior margin convex; urogastric region broad. swollen, U-shaped; posterior to margin of metagastric, not bilobed; hepatic region gently swollen. Cervical groove poorly defined, sinuous, U-shaped; interrupted medially by urogastric region; terminates posteriad hepatic region. 


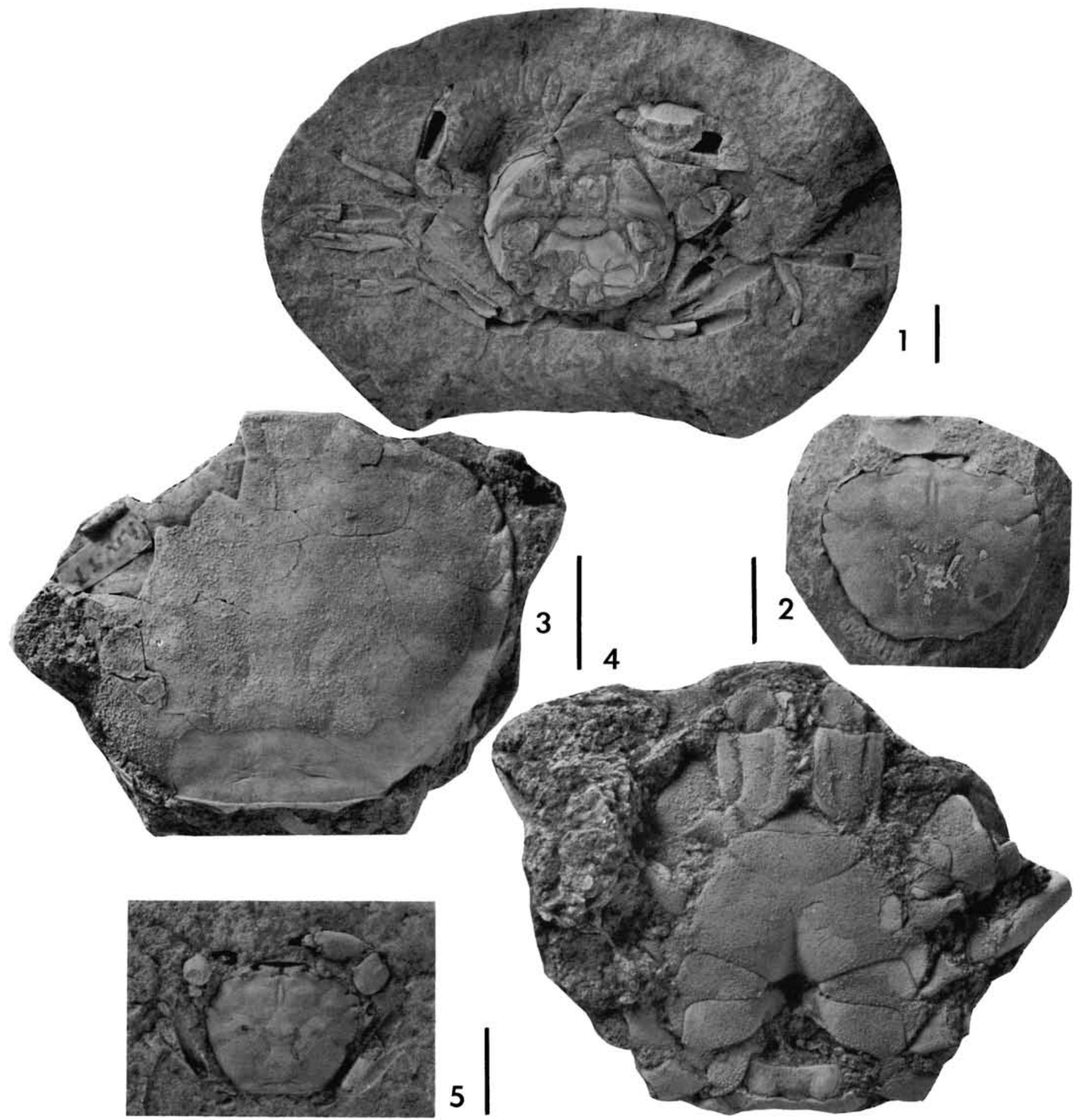

FIGURE 8-Neopilumnoplax hannibalanus (Rathbun). 1, partial ventral view of USNM 431272; 2, 3, and 5, dorsal views of USNM 431274, USNM 431280, and USNM 431275; 4, ventral view of USNM 431280 . Scale bars equal $1 \mathrm{~cm}$.

Cardiac region well marked by urn-shaped groove; branchiocardiac grooves deeply etched arcs directed axially; intestinal region marked by gently sinuous narrow grooves defining pits at base of cardiac region.

Epibranchial region small, weakly swollen, bearing fourth anterolateral tooth on outer margin; mesobranchial strongly arched, swollen medially, extending as ridge which terminates distally at fifth tooth, terminates axially at banchial-cardiac groove.

First two abdominal somites exposed dorsally, remainder folded ventrally; width of first three somites increases posteriorly from about one-fourth to about one-third extreme carapace width, width decreases on somites 4-7; length of abdominal 
TABLE 2-Representative measurements of Neopilumnoplax hannibalanus (in $\mathrm{mm}$ ).

\begin{tabular}{ccccccrrrr}
\hline \hline Specimen number & L & W & F & O & F-O & Al & Pl & P \\
\hline USNM 431278 & 37.8 & 43.8 & 13.8 & 7.6 & 19.0 & 15.0 & 21.6 & 11.3 & 7.7 \\
USNM 431274 & 22.2 & 27.0 & 7.9 & 5.2 & 18.3 & 7.5 & 14.1 & 7.5 \\
USNM 431274 & 16.0 & 18.5 & 5.7 & 3.8 & 12.5 & 5.1 & 9.9 & 4.8 & 3.4 \\
\hline
\end{tabular}

Abbreviations as in Table 1.

somites increases to somite four, decreases to somite six, somites six and seven longest; seven triangular, posterior apex sharply rounded. Surfaces of somites coarsely, unevenly punctate; axial region elevated; pleural regions ridged, margins apparently concave on somites $4-7$.

Sternum narrow, widening posteriorly, maximum width posterior to first pereiopod, depressed axially; surface coarsely and unevenly granulate. Sternite four as long as broad; five and six broader than long; seven obovate in outline, tapering to point anteriorly; eight unknown.

Pterygostomian region large, well-defined, triangular surface, broadly ridged, ridges pustulose; buccal cavity generally quadrate, widens slightly anteriorly, nearly closed by external maxillipeds.

Thoracic appendages strong; third maxilliped with ischium longer than broad, grooved longitudinally at inner one-third, flaring outward posteriorly; exognath straight, terminating posteriorly at flared part of ischium; merus of third maxilliped as broad as long, articulating with ischium just distal to ischium groove; margins raised, granulate; length marked by broad, arcuate furrow; palp strongly incurved.

Coxa of first pereiopod wider than long; basis with slightly concave anterior margin; ischium longer than broad, widening distally; merus much longer than wide, tapering distally; carpus quadrate, bearing interior acute tooth. Manus of major cheliped longer than high, punctate; propodus and dactylus unknown. Third and fourth pereiopods longest. Meri of ambulatory limbs somewhat compressed; ovate in cross section, ornamented by transverse ridges on anterior margins. Carpi carinate along anterior margin; dactyli lanceolate.

Measurements. - Measurements (in $\mathrm{mm}$ ) are given in Table 2.

Locality, type specimens, and occurrences. - The holotype, SU 5175, and one paratype, SU 5273, are deposited in the California Academy of Science, San Francisco, California.

Rathbun (1926) described Neopilumnoplax hannibalanus from the conglomerate cliffs at Koitlah Point on the Olympic Peninsula in Washington. These rocks have been assigned a late Eocene age (Snavely et al., 1978). Rathbun (1926) also recognized the species from the late Eocene Cowlitz Formation in Washington and from middle Oligocene rocks near Nehalem Bay, Oregon.

Specimens referable to this taxon were collected from localities 64 APr 255C (USNM 431277 and USNM 431279), in the Orca Group, and M 1222 (USNM 431273, USNM 431274, and USNM 431275), M1227 (USNM 431272), and $53 \mathrm{AMr} 14 \mathrm{M}$ (USNM 431278) along the west shore of Bering Lake, probably in the Tokun Formation (Marincovich, personal commun.); in addition, two specimens were collected from the west bank of the Nehalem River at a bend approximately 0.9 miles SE of Sunset Junction, Washington County, Oregon (USNM 431280 and USNM 431281), and one specimen from an unknown locality (USNM 431276). These are deposited in the United States National Museum of Natural History.

Remarks. - Stimpson (1858) introduced the generic name $\mathrm{Pi}$ lumnoplax to embrace four Japanese species, with its type species Pilumnoplax sulcatifrons Stimpson, 1858. In 1918. Tesch assigned P. sulcatifrons to Eucrate de Haan, 1835. Thus, Pilum- noplax became the junior subjective synonym of Eucrate. The three remaining original species also were assigned to other genera. Pilumnoplax longipes and $P$. ciliata were assigned to Heteropilumnus Tesch, 1918, and P. sculpta was assigned to Lophoplax Tesch, 1918. Many paleontologists continued to apply the name Pilumnoplax, for instance, Balss (1957) and Glaessner (1969) (Manning and Holthuis, 1981). Serène (1968) recognized that it would be necessary to introduce a new genus to embrace some of the species referred to Pilumnoplax, subsequent to the work of Tesch (Manning and Holthuis, 1981). Therefore, Serène initially introduced Neopilumnoplax, as a manuscript name to embrace five Indo-West Pacific species: $P$. heterochir Studer, 1882, P. sinclari Alcock, 1899, P. abyssicola Miers, 1886, $P$. cooki Rathbun, 1911, and, questionably, $P$. acanthomerus Rathbun, 1911. Subsequently, Guinot formalized the name. The type species for Neopilumnoplax is $P$. heterochir.

Guinot (1969b) concurred with Serène's newly established genus. However, she restricted assignment of species to the new genus to $P$. heterochir, $P$. americana Rathbun, 1898, and $P$. sinclairi (Manning and Holthuis, 1981). Pilumnoplax abyssicola and $P$. cook $i$ were reassigned to Carcinoplax, and $P$. acanomerus was left unassigned by Guinot (1969c). Subsequently, Manning and Holthuis (1981) reassigned $P$. atlantica Miers, 1881, and $P$. oxyacantha Monod, 1856 , to the genus Machaerus Leach, 1818.

Although the extant species of Pilumnoplax have been studied thoroughly and their taxonomic assignments reviewed, there has been no analysis of the assignments of three fossil species to this genus by Rathbun (1926). Rathbun recognized P. hannibalanus, $P$. soledadensis, and $P$. carmanahensis from Washington and Oregon. In view of the abandonment of the genus Pilumnoplax, these fossil species require re-evaluation.

It must be noted that many of the new assignments by different carcinologists reflect advances in the understanding of the complex relationships within the Goneplacidae. For example, Guinot $(1969 \mathrm{a}, 1969 \mathrm{~b}, 1969 \mathrm{c})$ has based many reassignments on sexual characteristics, especially the position of the male gonoduct. Unfortunately, these characteristics often are not well preserved in the fossil record. Consequently, re-evaluation of the fossil specimens will continue to depend on preservable characters, although these are not always satisfactory for differentiating genera within this complex family.

There does appear to be a strong correlation between the shape and position of the seventh and eighth sternites, their relationship to the insertion of the fifth coxa, and the placement of the male gonoduct. Thus, although the gonoduct itself is not observable on a fossil, these relationships may indicate the placement of the gonoduct. These characteristics may be employed to recognize different genera within the Goneplacidae, and to recognize subfamilies within the family.

Other characters of generic importance within the Goneplacidae include: the shape of the carapace, the definition of the regions on the dorsal carapace, the curvature of the anterolateral margin, the number of teeth on the anterolateral margin, the curvature and lobation of the front margin, the degree of convergence of the posterolateral margins, the shape and position 
of the third maxillipeds, and fusion of the abdominal somites. Characters used to define species are more subtle. These include: the convexity or concavity of the margins of the abdominal somites, the shape of the anterolateral teeth, the shape and decoration of the chelae, the relative convexity of the regions of the dorsal carapace, and the definition of the posterior margin.

The shape and position of the seventh sternite indicate that Neopilumnoplax hannibalanus is a member of the Euryplacinae. The abdominal somites 1-3 appear to cover the entire sternal width between the fifth coxa. The regions are not well defined, the front is usually square, often little deflexed, and the buccal cavity is quadrate and almost closed by the external maxillipeds, which have subquadrate meri.

Neopilumnoplax hannibalanus is difficult to distinguish from Branchioplax washingtoniana. The first two teeth are coalesced to form a straight margin on $B$. washingtoniana as they are on $N$. hannibalanus. This is a character that does not occur in many genera within the Goneplacidae. The shape and size of the third maxillipeds are quite similar on both genera, as is the general shape of the abdomen (USNM 431271 and USNM 431281; Figures 7,9). Posterolateral margins of $N$. hannibalanus converge more noticeably than those of $B$. washingtoniana and the regions on the dorsal carapace of $N$. hannibalanus are not as clearly marked. Margins of the sixth abdominal somite are convex on $B$. washingtoniana, not straight or slightly concave as with $N$. hannibalanus.

Neopilumnoplax hannibalanus shares several characters with the type species, Neopilumnoplax heterochir. The maxillipeds are similarly placed, the sternites are similar in shape and size, and the posterolateral margins converge. The seventh abdominal somite of $N$. heterochir is more rounded than with $N$. hannibalanus (Figure 9).

The two other fossil species referred to Pilumnoplax (Rathbun, 1926) require further study before they can be assigned to another genus. Pilumnoplax carmanahensis was described by Rathbun (1926) as having many features in common with $P$. americana and eventually may be placed with Neopilumnoplax. Pilumnoplax soledadensis has a rather short front margin which is distinctly bimarginate. This character probably cannot be accommodated by the variation with Neopilumnoplax.

\section{Genus Orbitoplax n. gen.}

Diagnosis. - As for the type species.

Description. - As for the type species.

Type genus. - Orbitoplax plafkeri n. sp., the sole included species.

Etymology. - "Orbito," refers to the elongate orbital ridges. "Plax" is a Greek word which means tablet. Many of the Goneplacidae possess a carapace which has a flat appearance. Thus, the word "plax" is often used for the Goneplacidae and its use suggests that a genus is a member of that family.

Geographic and stratigraphic location.-As for species.

\section{ORBITOPLAX PLAFKERI n. sp.}

Figure 10.1-10.5

Diagnosis.-Carapace hexagonal, slightly wider than long, longitudinally convex; orbits wide, facing forward; two narrow fissures in supraorbital ridge; front projecting, wide, equal to length of supraorbital ridge; margin straight, with tiny medial notch; fronto-orbital width slightly greater than 80 percent total width; anterolateral margin short, bearing only extraorbital spine and anterolateral spine; regions well defined; branchial regions much swollen; heterochelate; carpus longer than broad.

Description. - Carapace hexagonal, slightly broader than long, widest at anterolateral angle; length ranges from $13.4 \mathrm{~mm}$ to $18.5 \mathrm{~mm}$; slightly convex transversely, smoothly convex lon-

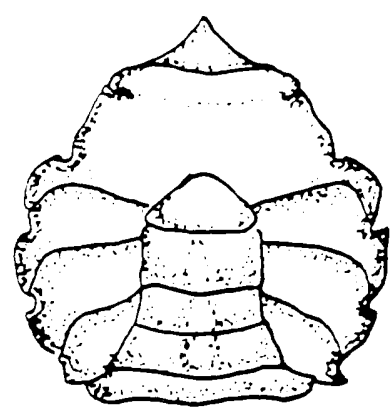

1

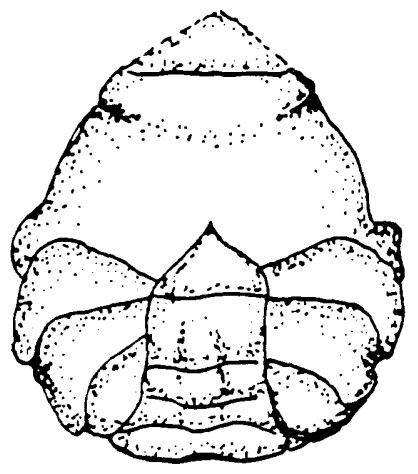

2

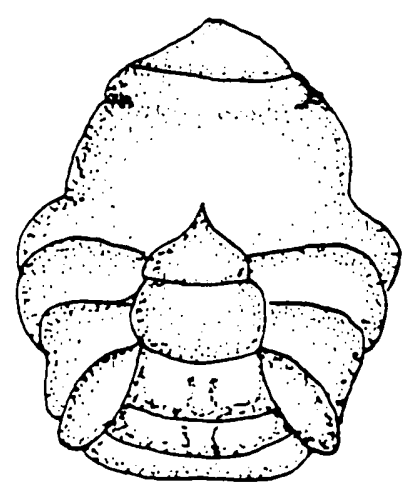

3

Figure 9-Line drawings comparing ventral surfaces of 1, Neopilumnoplax heterochir (Stimpson), after Guinot (1969c); 2, Neopilumnoplax hannibalanus, and 3, Brachioplax washingtoniana.

gitudinally; flanks turned slightly under at anterolateral angle and anterior to angle, becoming vertical and tapering posterior to anterolateral angle; regions moderately well marked by shallow grooves; posterior surface of dorsal carapace finely punctate, anterior surface less so.

Front wide, about 30 percent total width, produced and downturned at margin; margin straight, only slight medial notch; 


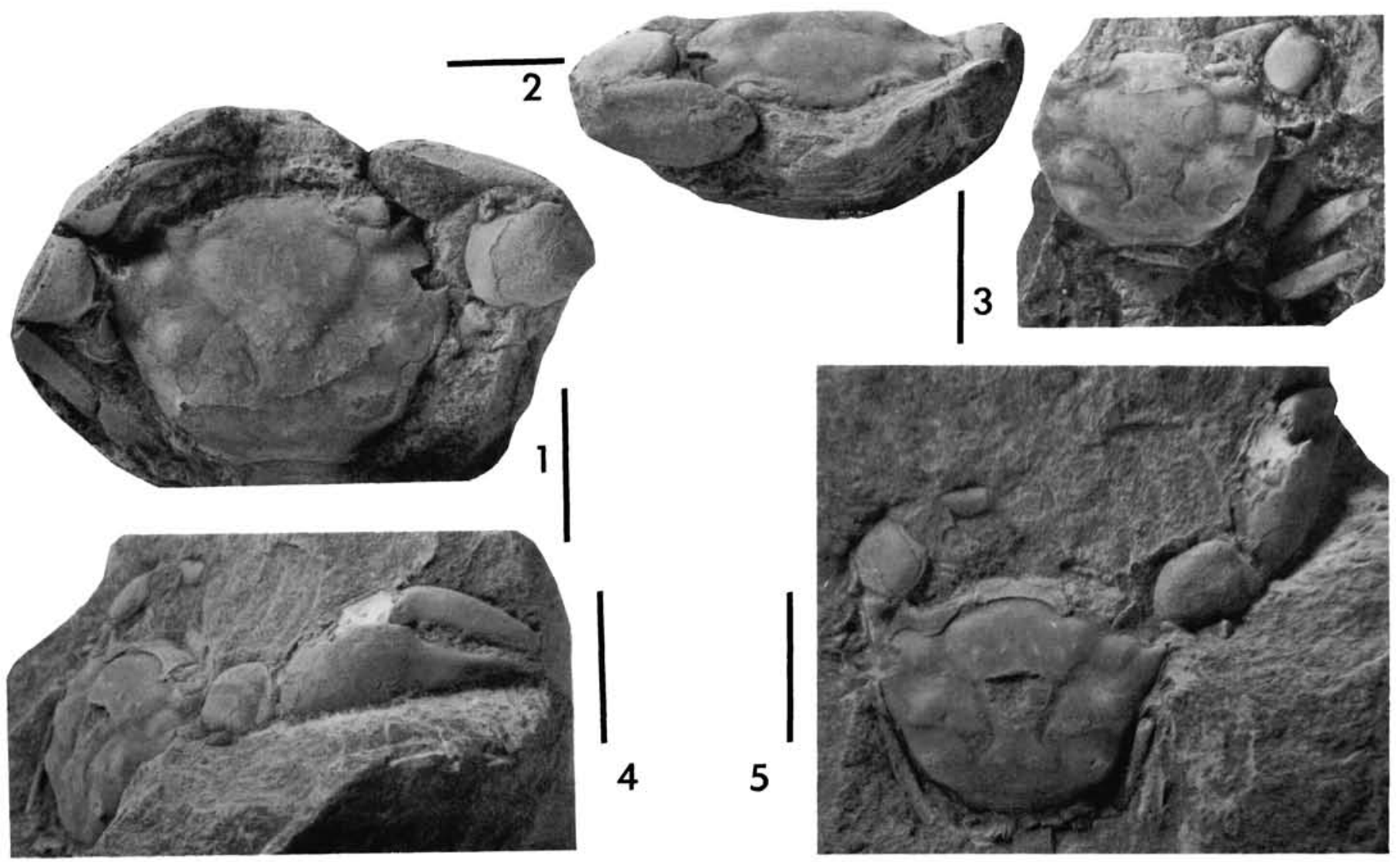

FIGURE 10-Orbitoplax plafkeri $\mathrm{n}$. gen. and sp. 1, 2, dorsal and frontal views of paratype USNM 431282; 3 , dorsal view of paratype USNM $431283 ; 4,5$, lateral view of right chela and dorsal view of carapace of holotype USNM 431285 . Scale bars equal $1 \mathrm{~cm}$.

corners sharply squared; orbits fairly deeply concave, directed forward and slightly upward; supraorbital margin raised, bearing two shallow notches; extraorbital tooth small, directed more forward than out, subacute; eye with well-developed ocular peduncle, widening distally.

Anterolateral margin short, slightly more than 25 percent total length, somewhat arcuate, converging anteriorly from anterolateral tooth to extraorbital tooth; no other teeth; anterolateral tooth large, as seen by base, pointing more forward and upward than out; posterolateral margin long, about 70 percent total length, sinuous, converging posteriorly; posterolateral corner a re-entrant, subtle marginal rim; posterior margin concave with narrow marginal rim.

Regions defined by broad shallow grooves; swollen, raised areas bearing granules; epigastric region broad, gently swollen, not well defined, separated from orbits by broad shallow furrow, not easily separated from protogastric or mesogastric regions; protogastric region broadly swollen, ovate in outline, axis of oval diverging anteriorly from long axis of animal, separated from hepatic region by shallow grooves, not well separated from mesogastric region, separated from metagastric region by very shallow furrow; mesogastric region poorly defined, narrow extension of anterior metagastric region, tapering forward, disappearing just posteriad medial notch in front margin; metagastric region triangular, tapering forward, merging with mesogastric; two nodes and granular muscle attachment scars along arcuate base; urogastric region indistinct; hepatic area broadly swollen, separated from margin of dorsal carapace by shallow furrow.
Cervical groove well defined, sinuous and broadly U-shaped, interrupted medially by urogastric region; cardiac region urnshaped, bearing three pustules forming triangle, apex directed posteriorly; branchiocardiac grooves fairly deep axially directed arcs; intestinal region small, poorly defined.

Epibranchial region not swollen, anterolateral tooth on outer margin; inflated boss at midpoint of mesobranchial regions, boss tapers into ridge which extends to inner angle of branchial region, tapers distally to form cristate edge with side just posteriad anterolateral spine; large boss at midpoint of metabranchial region, boss covered by fine granules.

Ventral aspects of carapace, including sternum, unknown. First two abdominal segments visible dorsally.

Chelipeds unequal, coarsely punctate, right much larger than left; meri of chelipeds longer than broad, incurved medially, projecting little beyond body, widening distally; carpi rounded, longer than broad; hand robust, palm nearly twice as long as high, widens distally; propodus long, slender, slightly flexed; teeth on occlusal surface of propodus broadly triangular; ambulatory appendages flattened, ovate in cross section, a series of short transverse ridges along anterior dorsal margin of meri.

Measurements. - Measurements (in $\mathrm{mm}$ ) are listed in Table 3 and illustrated in Figure 11.

Etymology. - This species was named for George Plafker who has worked for many years in Alaska with the U.S. Geological Survey and who collected these specimens during the 1972 field season.

Types.-Holotype, USNM 431285, and paratypes, USNM 431252, USNM 431282, USNM 431283, USNM 431284, 
TABLE 3-Representative measurements of Obitoplax plafkeri (in mm).

\begin{tabular}{|c|c|c|c|c|c|c|c|c|c|c|}
\hline Specimen number & $\mathrm{L}$ & W & $\mathrm{F}$ & $\mathrm{O}$ & $\mathrm{F}-\mathrm{O}$ & $\mathrm{Al}$ & $\mathrm{Pl}$ & $\mathrm{P}$ & $\mathrm{B}-\mathrm{C}$ & $\mathrm{C}$ \\
\hline USNM 431282 & 18.5 & 21.9 & 6.6 & $\begin{array}{l}6.6 \mathrm{R} \\
5.8 \mathrm{~L}\end{array}$ & 18.8 & 4.8 & 13.2 & 12.7 & 4.1 & $\begin{array}{l}9.5 \mathrm{~L} \\
6.9 \mathrm{~W}\end{array}$ \\
\hline USNM 431283 & 13.4 & 16.2 & 4.6 & 4.7 & 14.0 & 3.8 & 9.5 & 5.4 & 2.9 & $\begin{array}{l}5.0 \mathrm{~L} \\
4.1 \mathrm{~W}\end{array}$ \\
\hline $\begin{array}{l}\text { USNM } 431284 \\
\text { USNM } 431285\end{array}$ & $\begin{array}{l}16.6 \\
16.1\end{array}$ & $\begin{array}{l}19.1 \\
18.1\end{array}$ & 5.5 & 5.5 & 16.5 & $\begin{array}{l}4.4 ? \\
3.5\end{array}$ & 10.4 & 5.9 & 3.8 & \\
\hline
\end{tabular}

Abbreviations as in Table 1 .

USNM 431286, USNM 431287, and USNM 431288, deposited in the United States National Museum of Natural History.

Type locality. - The type locality is USGS field locality 72 APr 33D, on the south end of Wingham Island, along the shore, $2,200 \mathrm{ft}$ south of latitude $60^{\circ} \mathrm{N}, 8,400 \mathrm{ft}$ west of longitude $144^{\circ} 20^{\prime} \mathrm{W}$, Middleton Island (D-1 and D-2) 15' quadrangle.

Stratigraphic and geographic ranges. - The specimens were collected from the lower part of the Poul Creek Formation on Wingham Island in the Gulf of Alaska (Figures 1, 12). The lower Poul Creek Formation has been assigned a late Eocene to early Oligocene age. Members of this genus also have been identified from the Blue Mountain Member of the Crescent Formation, Olympic Peninsula, Washington.

Remarks. - This taxon is represented by eight specimens. One is preserved as a mold of the interior with part of the right and left carpi exposed, and part of the propodus of the right cheliped (USNM 431282). Another of the specimens is a well-preserved mold of the interior of the cephalothorax, with the left flank and the carpus of the right cheliped exposed (USNM 431283). The dorsal surface of the carapace is partially covered with broken, replaced integument and exhibits part of the meri of some of the ambulatory appendages. A third specimen is preserved as an internal mold which has preserved the entire right chela (USNM 431285). The anterolateral spine has not been preserved on any of the specimens. All of the specimens were preserved in calcareous concretions.

Certain of the Goneplacidae share some characters with the Xanthidae, which makes assignment of a fossil specimen to a precise systematic position problematic. The problem is compounded by the reliance on the position of the male genital duct for separation of the two families. Although these characters may be reliable criteria on living specimens, they impose severe restrictions for the study of fossils. Genital openings are not commonly observed in the fossil record. In addition, the ventral surface of the cephalothorax is not preserved on every specimen. Another character, whether or not sternite 8 of the male is exposed between the second abdominal segment and the coxa of the fifth pereiopod, is not always observable. When the ventral surface is not exposed, the specimen cannot be sexed with certainty and, often, dorsal exposure of the abdominal somites reveals displacement of these segments from the cephalothorax.

There are, however, certain characteristics of the dorsal carapace that can be used to refer a specimen to the Goneplacidae with some assurance. One is the length of the fronto-orbital margin relative to the greatest width of the carapace. The frontoorbital margin is never more than 80 percent of the greatest width in the Xanthidae and can exceed this proportion within the Goneplacidae (Williams, 1984). Additionally, although there may be occasional exceptions, elongation of the supraorbital ridges is a character found in the Goneplacidae. Orbitoplax plafkeri should be referred to the Goneplacidae, based on the elongation of the orbits and the length of the fronto-orbital margin, which is always slightly greater than 80 percent of the total width (Table 3).
Within the Goneplacidae, Orbitoplax can be eliminated immediately from certain subfamilies. The carapace of the Goneplacinae is subquadrate and widest between the extraorbital angles; Orbitoplax is hexagonal in outline and widest between the anterolateral angles. Styrioplax (=Microplax Glaessner, 1928) has small orbits. This leaves the genera within the Euryplacinae, Carcinoplacinae, and Eucratopsinae (Prionoplacinae). Since keying within the subfamilies of the Goneplacidae primarily is based upon male abdominal and sexual characteristics, it is not prudent to try to refer Orbitoplax to one of these subfamilies. Rather, the wiser choice is to compare Orbitoplax with the known genera in the remaining subfamilies.

Within the Euryplacinae, Orbitoplax plafkeri possesses characters most like those of the extant genus, Euryplax Stimpson (1859). However, Euryplax spp. have a carapace that is smooth, much broader than long, with three strong teeth on the anterolateral margin. In addition, the anterolateral margin is much longer than with those of Orbitoplax. Eucrate de Haan (1835), an extant genus known also from the Tertiary, embraces species characterized by a bilobate front and a subquadrilateral carapace with small orbits and lobate anterolateral borders. Characteristics of the extant genus Heteroplax Stimpson, 1858, are somewhat similar to those of Orbitoplax; however, Heteroplax has a carapace that is broadest between the external orbital angles and appears quadrate in outline. Species of Frevillea A. Milne Edwards (1880), an extant genus, are much broader than those of Orbitoplax, with the greatest width between the extraorbital teeth. Trizocarcinus Rathbun (1914) are characterized by a carapace that is quadrilateral in shape, and anterolateral margins with three strong teeth. Machaerus Leach, 1818, is an extant genus distinguished by a smooth carapace bearing three or four pairs of anterolateral teeth and a short front margin.

Of the fossil genera within the Carcinoplacinae, Orbitoplax plafkeri is most like species within Glyphithyreus Reuss (1859) from the Eocene. Orbitoplax spp. have a projecting front which is as wide as each supraorbital margin, short anterolateral margins, and two fissures along the supraorbital ridge, as does $G / y^{\prime}$ phithyreus; however, the orbits and front of Orbitoplax spp. are much wider and there is no medial sulcus on the front as in Glyphithyreus. Of the other fossil genera, Branchioplax Rathbun (1926) has shorter orbital margins, is not convex, and has five anterolateral spines. Species of Carcinoplacoides Kesling (1958) are transversely oval and smooth, rather than marked by grooves. Carcinocarcinus Lorenthey (1898) have small orbits and four anterolateral teeth. The deflexed front of Galenopsis A. Milne Edwards (1865) is medially sulcate and the orbits are much smaller than in Orbitoplax. The carapace of the Laevicarcinus Lorenthey and Beurlen (1929) is flat, not convex, and the anterolateral margin is four-lobed. Martinezicancer Van Straelen (1939) has a supraorbital spine and two posterolateral teeth not found on members of Orbitoplax. Tehuacana Stenzel (1944) have a square carapace with the fronto-orbital margin 70 percent of the greatest width.

Of the extant genera in the Carcinoplacinae, members of $\mathrm{Or}$ - 

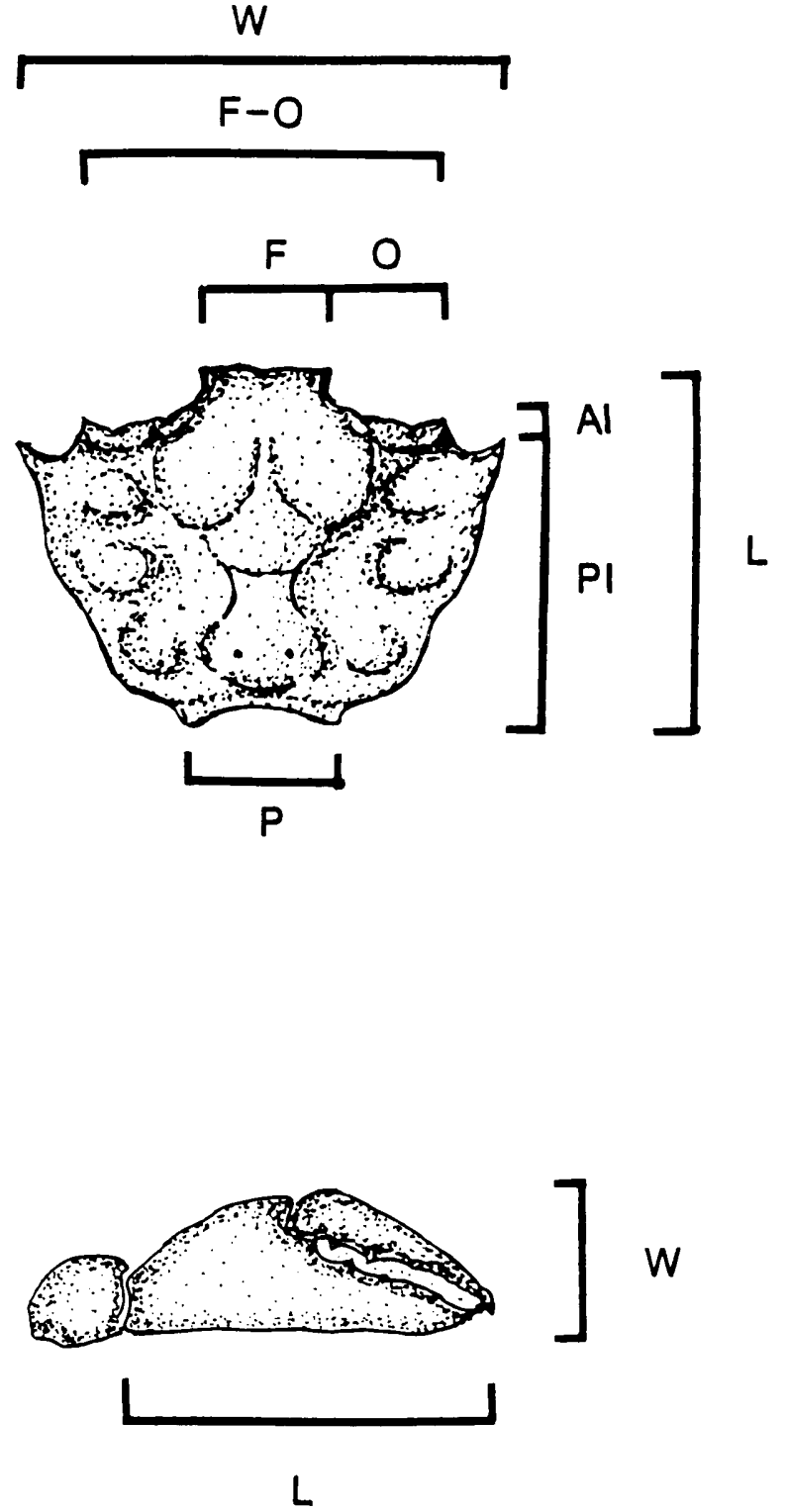

FIGURE 11 - Line drawings of dorsal view of carapace (top) and right chela (bottom) of Orbitoplax plafkeri n. gen. and sp., showing positions of measurements given in Table $3 . \mathrm{L}=$ length, $\mathrm{W}=$ width, $\mathrm{F}$ $=$ front margin, $\mathrm{O}=$ supraorbital margin, $\mathrm{F}-\mathrm{O}=$ fronto-orbital length, $\mathrm{Al}=$ anterolateral margin, $\mathrm{Pl}=$ posterolateral margin, $\mathrm{P}=$ posterior margin.

bitoplax most resemble species of Psopheticus Alcock, 1894. Psopheticus spp. possess wide orbital ridges and two anterolateral teeth. However, the anterolateral margin of the three species embraced within this genus is much longer than that exhibited by the species of Orbitoplax. Additionally, the front margins of Psopheticus spp. are narrower and the orbits wider. Consequently, the orbital margins of Psopheticus spp. are noticeably longer than the front margin. Most importantly, the outline of the carapace of Psopheticus spp. has a quadrate appearance because the posterolateral margins do not converge. Of the other extant genera, the carapace of species embraced by Neopilumnoplax Serène, 1969, is depressed and the fronto-orbital border is only 70 percent of the total width of the carapace. Carcinoplax

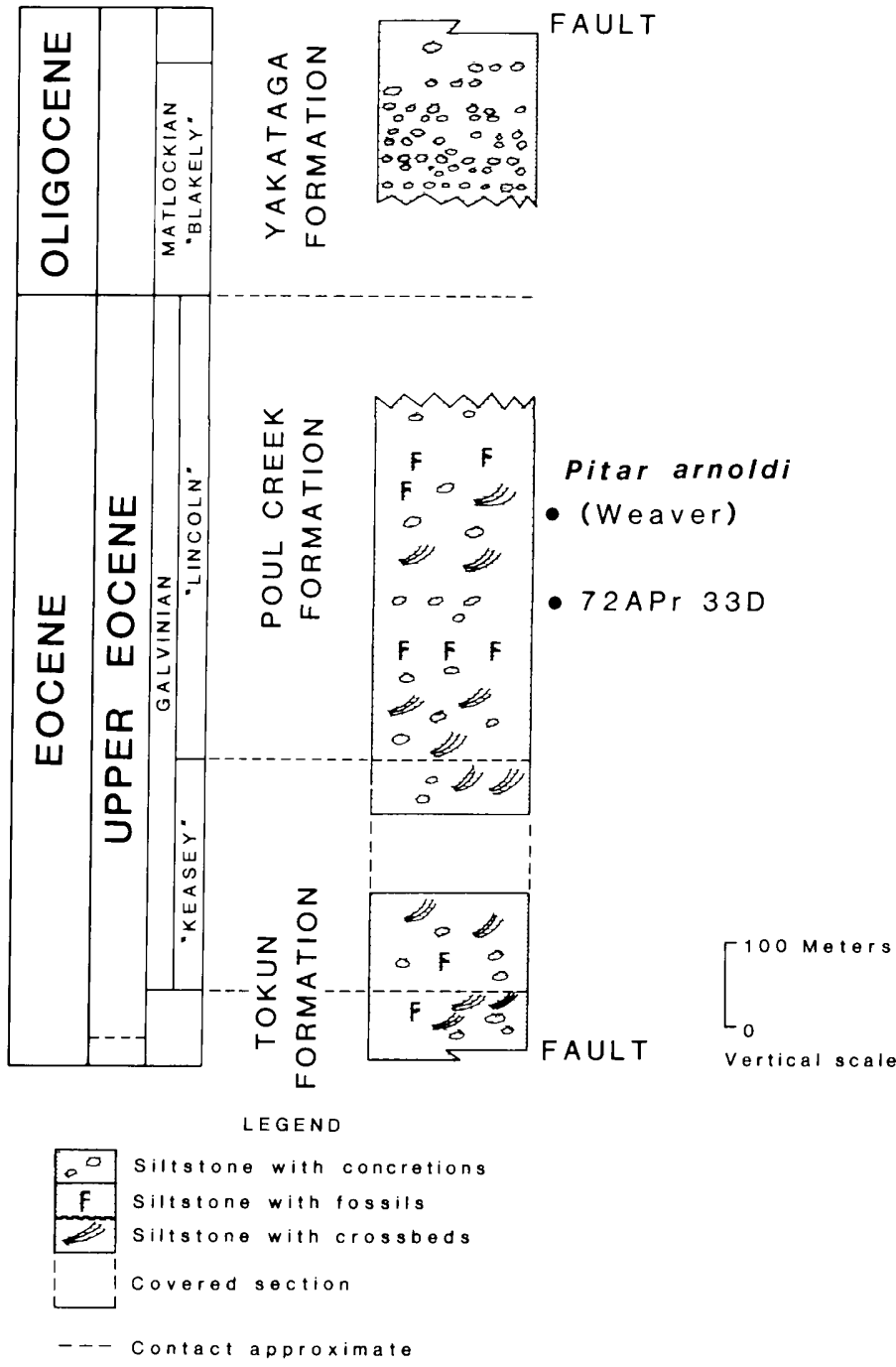

FIGURE 12 - Representative stratigraphic column of the Paleogene formations on Wingham Island. The position from which Orbitoplax plafkeri n. gen. and sp. was collected is indicated, as is the position of Pitar arnoldi. (After Addicott, 1978, in Plafker, 1987.)

H. Milne Edwards (1852) are defined as transversely oval with three anterolateral teeth and small orbital margins. Although species of Carcinoplax demonstrate great variation within the genus, none of the species embraced by the genus exhibit the wide orbits of Orbitoplax:

Of the extant genera in the Eucratopsinae, members of $\mathrm{Or}$ bitoplax most resemble species of Glyptoplax Smith (1870). However, Glyptoplax spp. have shorter supraorbital ridges and anterolateral borders with four teeth. Additionally, the carpi of the major chelipeds of the Orbitoplax are more rectangular and the meri of the walking legs are broader. Prionoplax H. Milne Edwards (1852) are characterized by a trapezoidal carapace with the anterolateral margin continuous with the posterolateral margin. Panoplax Stimpson (1871) are defined by a depressed carapace and small orbits. Species of Tetraplax Rathbun (1900) have dentate anterolateral margins and a front that is medially sulcate. In addition, the posterolateral margin of Tetraplax spp. is more convergent than with the species of Orbitoplax: 
Nannoplax Guinot (1967) and Pseudorhombilia H. Milne Edwards (1834) embrace species that resemble Orbitoplax spp.; however, Nannoplax spp. have smaller orbits and sinuous front margins. Pseudorhombilia spp. have a much shorter frontoorbital margin, only 50 percent of the total width of the carapace. The fronto-orbital border of species within Eucratopsis Smith (1869) is from three-fifths to two-thirds the total width of the carapace and the orbital ridges bear three notches. Oediplax Rathbun (1893) is characterized by a broader carapace and much smaller orbits. Species of Speocarcinus Stimpson (1859) are defined by a depressed carapace with five teeth on the anterolateral border, and much smaller orbits than those of Orbitoplax.

Orbitoplax is distinct among the Goneplacidae. The elongate orbits, which are the same length as the orbital margins, set this genus apart. In addition, the convex shape, well-defined regions of the dorsal carapace, and convergent posterolateral margins make this a unique taxon.

Orbitoplax sp. has recently been discovered in the Blue Mountain Member of the Eocene Crescent Formation, Olympic Peninsula, Washington. This implies that the genus may have originated south of the Gulf of Alaska. Because the specimens from Washington have not been thoroughly studied, it is not possible to comment on their species identity at this time.

\section{SUMMARY AND CONCLUSIONS}

Rathbun (1926) originally described the Pacific West Coast decapods. Utilizing specimens from Alaska, and several others discovered since 1926 from Washington, redescriptions of five Pacific Coast species recognized to occur in the Alaskan assemblages have been made. Raninoides vaderensis, Eumorphocorvstes naselensis, Portunites alaskensis, and Branchioplax washingtoniana are recognized. Pilumnoplax hannibalanus is reassigned to Neopilumnoplax. One new genus and species, Orbitoplax plafkeri, is described from the Poul Creek Formation on Wingham Island.

The stratigraphic position of the sequence of rocks at Koitlah Point, Olympic Peninsula, Washington, has been significantly refined since Rathbun (1926) originally described the decapod fauna. Rathbun made her age interpretations before the era of microfossil biochronology. New information, based on molluscs and foraminiferans, indicates a late Eocene age for this sequence, rather than Oligocene as Rathbun suggested. These revised age assignments place some doubt on the decapod ranges as originally suggested by Rathbun (1926) and limit the biochronological usefulness of decapod taxa, unless combined with molluscan taxa. Further, this suggests that other decapod age determinations may require re-evaluation in the context of more recent stratigraphic correlations.

The occurrence of Raninoides vaderensis within Orca deposits appears to corroborate an Eocene age for the Orca Group as suggested by Plafker et al. (1985). The Orca Group probably was deposited before the end of the middle Eocene. This is compatible with the range of ages for the different discordant plutons intruding the Orca Group. Based on this evidence, the ranges of Neopilumnoplax hannibalamus and Branchioplax washingtoniana must be extended to include the middle Eocene. The occurrence of a new genus and species of goneplacid from Alaska and Washington adds to the diversity of the Pacific West Coast decapod fauna.

\section{ACKNOWLEDGMENTS}

Specimens forming the basis of this study were offered by Ellen Moore, U.S. Geological Survey, retired, Menlo Park, Cal- ifornia. Austin Williams, National Museum of Natural History, Washington, D.C., offered numerous helpful comments on the morphology of extant goneplacids. George Plafker, U.S. Geological Survey, Menlo Park, read an early draft of the location and stratigraphy section of the manuscript and offered many suggestions to improve this section. Louie Marincovich, U.S. Geological Survey, Menlo Park, discussed many aspects of the stratigraphy in Alaska and helped to obtain the necessary references for locality maps and measured sections. Useful reviews were provided by G. A. Bishop and J. D. Nations. The curatorial staff at the United States National Museum of Natural History, the Natural History Museum of Los Angeles County, and the California Academy of Science made available some of the specimens studied. The Amoco Production Company supported the senior author during the course of the work. Contribution 434 , Department of Geology, Kent State University, Kent, Ohio 44242 .

\section{REFERENCES}

Addicott, W. O., and G. Plafker. 1971. Paleocene mollusks from the Gulf of Alaska, Tertiary Province-a significant new occurrence, on the North Pacific rim. U.S. Geological Survey Professional Paper, 750-B:48-52.

AlCoCk, A. 1894. On the result of deep-sea dredging during the season of 1890-1891. In Natural History Notes from Indian Marine Survey Steamer "Investigator," Series II, No. 1. Annals and Magazine of Natural History, 6(13):225-245, 321-334, 400-411.

- 1899. An account of the deep-sea Brachyura collected by the Royal Indian Marine Survey ship "Investigator." Trustees of the Indian Museum, Calcutta, $85 \mathrm{p}$.

BALss, H. 1957. Decapoda. VIII. Systematik, p. 1505-1672. In H. G. Bronns, Klassen und Ordnungen des Tierreichs. Band 5, Abteilung I, Buch, 7, Lieferung 12.

BeLl, T. 1858. A monograph of the fossil malacostracous Crustacea of Great Britain, Pt. I, Crustacea of the London Clay. Palaeontographical Society, London, $44 \mathrm{p}$.

Bergrren, W. A., D. V. Kent, J. J. Flynn, and J. A. Van. Couvering. 1985. Cenozoic geochronology. Geological Socicty of American Bulletin, 96:1407-1418.

BinkHORST, J. T., VAN. 1857. Neue Krebs aus der Maestrichter Tuffkreide. Verhandlungen naturhistorische Verein preuss. Rheinl., 14: $107-110$.

BurkenroAd, M. D. 1963. The evolution of the Eucarida (Crustacea, Eumalacostraca), in relation to the fossil record. Tulane Studies in Geology, 2:3-16.

DANA. J. D. 1851. Conspectus Crustaceorum quae in Orbis Terrarum Circumnavigatione, Carolo Wilkes e Classe Riepublicae faederate Duce, Lexit et Descripsit. Proceedings of the Academy of Natural Sciences of Philadelphia, 5:247-254.

Feldmann, R. M. 1989. Lyreidus alseamus Rathbun from the Paleogene of Washington and Oregon, U.S.A. Annals of Carnegie Museum, $58: 61-70$.

GlaESSNER, M. F. 1928. Die Dekapodenfauna des öesterreichischen Jungtertiärs. [K.K.] Geologische Bundesanstalt Wien, Jahrbuch, 78(12): $161-219$.

- 1969. Decapoda, p. R399-R533. In Raymond C. Moore (ed.), Treatise on Invertebrate Paleontology, Pt. R. Arthropoda 4(2). Geological Society of America and University of Kansas Press, Lawrence.

Givinot, D. 1967. Recherches préliminaires sur les groupements naturels che $\%$ les crustacés décapodes brachyoures. II. Les anciens genres Micropanope Stimpson et Medaeus Dana. Bulletin du Muséum National d'Histoire Naturelle, Paris, sér. 2. 39:345-374.

- 1969a. Recherches préliminaires sur les groupements naturels chez les crustacés décapodes brachyoures. VII. Les Goneplacidae. Bulletin du Muséum National d’Histoire Naturelle, 2 Sérice, 41:241265.

- 1969b. Recherches préliminaires sur les groupements naturels chè les crustacés décapodes brachyoures. VII. Les Goneplacidae. Bulletin du Muséum National d’Histoire Naturelle, 2 Série, 41:507528. 
1969c. Recherches préliminaires sur les groupements naturels chez les crustacés décapodes brachyoures. VII. Les Goneplacidae. Bulletin du Muséum National d'Histoire Naturelle, 2 Série, 41:688724.

- 1977. Propositions pour une nouvelle classification des crustacés décapodes brachyoures. Compte rendu, Academie Science Paris (D), 285:1049-1052.

HAAN, W. DE. 1833-1950. Fauna Japonica sive descriptio animalium, quae in itinere per Japoniam, jussu et auspiciis superiorum, qui summum in India, Batava Imperium tenent, suscepto, annis 1823-1830 collegit, notis, observationibus et adumbrationibus illustravit. A. Arnz (Lugdunum Batavorum), $243 \mathrm{p}$.

JeLETZKY, J. A. 1973. Age and depositional environment of the lower part of Escalante Formation, western Vancouver Island, British Columbia (92-E): mollusks versus foraminifers. Canadian Journal of Earth Sciences, 10:331-365.

Kesling, R. V. 1958. Fossil crabs from Guam. Michigan University, Museum of Paleontology, Contributions, 14:207-263.

Latreille, P. A. 1803. Histoire naturelle, générale et particuliére, des crustacés et des insectes. Vol. 6. F. Dufart, Paris, 391 p.

- 1825. Entomologie, ou histoire nautrelle des crustacés, des arachnides et des insects. In Genre de Crustacés Encyclopedie Methodique. Histoire Naturelle, 10,832 p.

LEACH, W. E. 1817-1818. A general notice of the animals taken by Mr. John Cranch, during the expedition to explore the source of the River Zaire, p. 407-419. In J. K. Tuckey, Narrative of an Expedition to Explore the River Zaire, in 1816, under the direction of Captain J. K. Tuckey. R. N. John Murray, London.

LORENTHEY, E. 1898. Über die Brachyuren der paläontologischen Sammlung des bayerischen Staates. Termész. Füzetek, 21:134-152.

- AND K. Beurlen. 1929. Die fossilen Dekapoden der Länder der ungarischen Krone. Mathematische Naturwissenschaftliche, Berichte Ungarn, 25(3), $420 \mathrm{p}$.

MACLEAY, W.S. 1838. On the brachyurous decapod Crustacea brought from the Cape by Dr. Smith, p. 53-71. In A. Smith (ed.), Illustrations of the Zoology of South Africa, Invertebrata. Smith, Elder and Company, London, 5(3).

MacNeil, F. S., J. A. Wolfe, D. J. Miller, And D. M. Hopkins. 1961. Correlation of Tertiary formations of Alaska. American Association of Petroleum Geologists Bulletin, 45:1801-1809.

MANNing, R. B., AND L. B. Holthuis. 1981. West African brachyuran crabs (Crustacea: Decapoda). Smithsonian Contributions to Zoology, 306, $379 \mathrm{p}$.

Marincovich, L., JR., AND S. MCCOY, JR. 1984. An overview of Paleogene molluscan biostratigraphy and paleoecology of the Gulf of Alaska region. Palaeogeography, Palaeoclimatology, Palacoecology, 47:91-102.

Martin, G. C. 1908. Geology and mineral resources of the Controller Bay region, Alaska. U.S. Geological Survey Bulletin, 335:24-35.

. 1921. Preliminary report on petroleum in Alaska. U.S. Geological Survey Bulletin, 719:16-21.

Miers, E. J. 1881. On a collection of Crustacea made by Baron Hermann-Maltzan at Goree Island, Senegambia. Annals and Magazine of Natural History, ser. 5, 8:204-220, 259-281, 364-377.

1886. Report on the Brachyura collected by H. M. S. ('hallenger during the years 1873-76. Report on the Scientific Results of the Voyage of H. M. S. (hallenger. Zoology, 17(49), 362 p.

Milne Edwards, A. 1862-1865. Monographie des crustacés de la famille cancériens. Annals Science Naturelle, Zoologie, Série 4. 18(1862):31-85): 20(1863):273-324: sér. 5, 1(1864):31-88; 3(1865): 297-351.

- 1865. Descriptions de quelque crustacés noveaux, apportement à la tribu des Maiens. Annales Société Entomologie France, 4:133147.

- 1880 . Reports on the results of dredging under the supervision of Alexander Agassiz. in the Gulf of Mexico and in the Caribbean Sea, 1877, 78,79 , by the United States Coast Survey Steamer "Blake"...VII. - Etudes préliminaires sur les crustacés. Bulletin of the Museum of Comparative Zoology at Harvard College, 8(1), $68 \mathrm{p}$.

Milne Edwards, H. 1834-1840. Histoire naturelle des crustacés, comprenant l'anatomie, la physiologie et la classification de ces animaux. Libraire Encyclopédique de Roret. Paris, 2:532.

- 1852. Observations sur les affinités zoologiques et la classifi- cation naturelle des crustacés. Annals Science Naturelle, Zoologie, Série 3, 18:109-166.

Monod, T. 1856. Hippidea et Brachyura ouest-africains. Mémoires d l'Institut Français d'Afrique Noire, 45, 674 p.

Plafker, G. 1974. Preliminary Geologic Map of Kayak and Wingham Islands, Alaska. U.S. Geological Survey Open-File Report 74-82.

- 1987. Regional geology and petroleum potential of the Northern Gulf of Alaska continental margin, p. 229-268. In D. W. Scholl, A. Grantz, and J. G. Vedder (eds.), Geology and Resource Potential of the Continental Margin of Western North America and Adjacent Ocean Basins. Circumpacific Council for Energy and Mineral Resources.

- AND F. S. MACNEIL. 1966. Stratigraphic significance of Tertiary fossils from the Orca Group in the Prince William Sound region, Alaska, p. 62-68. In Geological Survey Research 1966, U.S. Geological Survey Professional Paper 550-B.

-, G. Keller, J. A. Barron, And J. R. Blueford. 1985. Paleontological data on the age of the Orca Group, Alaska. U.S. Geological Survey Open-File Report, 85-429, 20 p.

RAFINESQUE, C. S. 1815. Analyse de la nature, ou tableau de l'univers et des corps organisés. Palermo, 224 p.

RathBun, M. J. 1893. Descriptions of new genera and species of crabs from the west coast of North America and the Sandwich Islands. Proceedings U.S. National Museum, 16(933):223-260.

. 1898. The Brachyura of the biological expedition to the Florida Keys and the Bahamas in 1893. Bulletin from the Laboratories of Natural History of the State University of Iowa, 4(3), 294 p.

. 1900. The decapod and stomatopod Crustacea. Results of the Branner-Agassiz. Expedition to Brazil, I. Washington Academy of Science, 2:133-156.

- 1911. Marine Brachyura. The Percy Sladen Trust Expedition to the Indian Ocean in 1905, 3(9). Transactions of the Linnaeus Society London, (Zoology) (2), 14:191-261.

- 1914. New genera and species of American brachyrhynchous crabs. Proceedings of the U.S. National Museum, 47(2047):117-129.

- 1916. Description of a new genus and species of fossil crab from Port Townsend, Washington. American Journal of Science, 41:344346.

1926. The fossil stalk-eyed Crustacea of the Pacific slope of North America. U.S. National Museum, Bulletin 138, 155 p.

. 1932. Preliminary descriptions of new species of Japanese crabs

Proceedings of the Biological Society of Washington, 45:29-38.

- 1937. The oxystomatous and allied crabs of America. U.S. National Museum, Bulletin 166, 278 p.

Reuss, A. E. 1859. Zur Kenntnis fossiler Krabben. Akademic Wissenschaften, Wien, Denkschriften, 17:1-90.

SakaI, T. 1976. Crabs of Japan and the Adjacent Seas. Tokyo Kodansha Ldt., 24, 773 p.

SCHRADER, F. C. 1900. A reconnaissance of a part of Prince William Sound and the Copper River district, Alaska, in 1898. U.S. Geological Survey Special Publication, 94 p.

SERÈNE, R. 1968. The Brachyura of the Indo-West Pacific region. Prodromus for a check list of the (non-planktonic) marine fauna of south east Asia. (Indo-Pacific brachyurans), p. 33-112. In UNESCO. Fourth Meeting of Marine Sciences, Singapore, 1-4.

1969. Description de deux espèces nouvelles et redécouverte d'une espece de Brachyoure (Decapoda-Crustacea) dans les eaux d'Indonésie. Cahiers du Pacifique, 13 (mai 1969):281-293.

Smith, S. 1. 1869. Notes on new or little known species of American cancroid Crustacea. Proceedings of the Boston Society of Natural History, 12:274-289.

- 1870. Notes on American Crustacea, no. 1. Ocypodoidea. Transactions of the Connecticut Academy of Arts and Sciences, 2:113-176.

Snavely, P. D.. JR.. A. R. Niem, anid J. E. Pearl. 1978. Twin River Group (upper Eocene-lower Miocene) defined to include the Hoko River, Makah, and Pysht Formations, Clallam County, Washington. I.S. Geological Survey Bulletin. 1457:111-120.

Stenzel, H. B. 1944. A new Paleocene catometope crab from Texas, Tehuacana tehuacana. Journal of Paleontology, 18:546-549.

Sitevic, Z. 1971. The main features of brachyuran evolution. Systematic Zoology, 20:331-340.

Stimpson. W. 1858. Prodromus descriptionis animalium evertebratorum, quae in Expeditione ad Oceanum Pacificum Septentrionalem. 
a Republica Federata missa, Cadwaladaro Ringgold et Johanne Rodgers Ducibus, observavit et descripsit. Proceedings Academy of Natural Sciences Philadelphia, 10, Crustacea Ocypodoidea:93-110.

- 1859. Notes on North American Crustacea, I. Annals of the Lyceum of Natural History of New York, 7(1862)(2):49-93[1-47].

. 1871. Preliminary report on the Crustacea dredged in the Gulf Stream in the Straits of Florida by L. F. de Pourtales, assistant United States Coast Survey. Part I. Brachyura. Bulletin of the Museum of Comparative Zoology at Harvard College, 2:109-160.

STUDER, T. 1882. Verzeichniss der, während der Reise S. M. S. "Gazelle" an der Westküste von Afrika, Ascension und dem Cap der guten Hoffnung, gesammelten Crustaceen. Abhandlungen Deutsche Akademie, der Wissenschaften, Berlin, 1882 [1883], 2:1-32.

Taliaferro, N. L. 1932. Geology of the Yakataga, Katalla and Nichawak districts, Alaska. Geological Society of America Bulletin, 43: 749-782.

Tesch, J. J. 1918. The Decapoda Brachyura of the Siboga Expedition. II. Goneplacidae and Pinnotheridae, p. 149-295. In Siboga-Expeditie, Monograph 39, livraison 84.

Tysdal, R. G., T. Hudson, and G. Plafker. 1976. Geologic map of the Cordova B-2 quadrangle and northern part of the Cordova A-2 quadrangle, southcentral Alaska. U.S. Geological Survey Miscellaneous Field Studies Map MF-783.

VAN Straelen, V. 1939. Martinezcancer schencki brachyure nouveau du Paléocène de Californie. Musée royal d'histoire naturelle de Belgique, Bulletin 15(63): 1-3.

WARner, G. F. 1977. The Biology of Crabs. Van Nostrand Reinhold Company, New York, 202 p.

Weaver, C. E. 1944. Correlation of the marine Cenozoic formations of Western North America. Geological Society of America Bulletin, 55:569-598.

Williams, A. B. 1984. Shrimps, Lobsters, and Crabs of the Atlantic Coast of the Eastern United States, Maine to Florida. Smithsonian Institution Press, Washington, D.C., 550 p.

Winkler, G. R. 1976. Deep-sea fan deposition of the lower Tertiary Orca Group, eastern Prince William Sound, Alaska. U.S. Geological Survey Open-File Report 76-83, 20 p.

WOLFE, J. A. 1977. Paleogene flora from the Gulf of Alaska region. U.S. Geological Survey Professional Paper 997, 108 p.

ACCEPTED 17 DECEMBER 1989 